Portland State University

PDXScholar

\title{
The Effects of Subsidized Childcare on Student Parents' Access to Higher Education at Portland State University
}

\author{
Elizabeth Dawn Creach \\ Portland State University
}

Follow this and additional works at: https://pdxscholar.library.pdx.edu/open_access_etds

Part of the Family, Life Course, and Society Commons, and the Higher Education Commons Let us know how access to this document benefits you.

\section{Recommended Citation}

Creach, Elizabeth Dawn, "The Effects of Subsidized Childcare on Student Parents' Access to Higher Education at Portland State University" (2003). Dissertations and Theses. Paper 3667.

https://doi.org/10.15760/etd.5551

This Thesis is brought to you for free and open access. It has been accepted for inclusion in Dissertations and Theses by an authorized administrator of PDXScholar. Please contact us if we can make this document more accessible: pdxscholar@pdx.edu. 


\section{THESIS APPROVAL}

The abstract and thesis of Elizabeth Dawn Creach for the Master of Science in

Sociology were presented November 5, 2003, and accepted by the thesis committee and the department.

COMMITTEE APPROVALS:

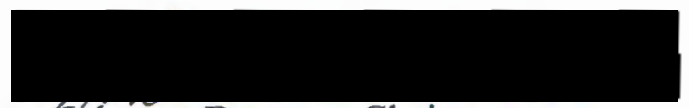

Johanna Brenner, Chair

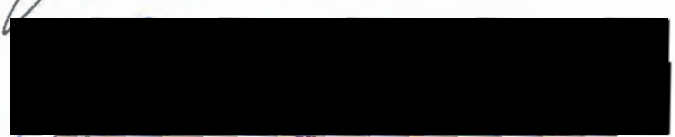

Daniel Sullivan

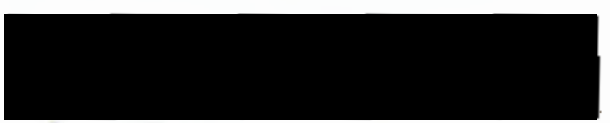

Grant Farr

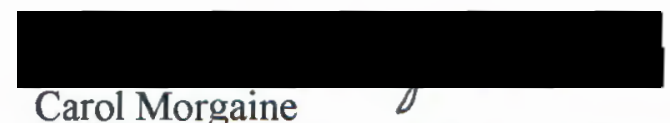

Representative of the Office of Graduate Studies

DEPARTMENT APPROVAL:

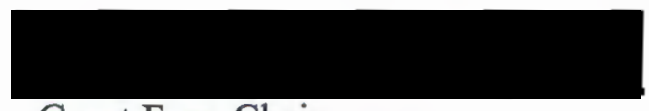

Grant Farr, Chair

Department of Sociology 


\begin{abstract}
An abstract of the thesis of Elizabeth Dawn Creach for the Master of Science in Sociology presented November 5, 2003.
\end{abstract}

Title: The Effects of Subsidized Childcare on Student Parents' Access to Higher Education at Portland State University.

Student parents are an increasing population of enrollees in higher education. However, access to quality and affordable childcare is a substantial barrier for student parents, especially women. Because high quality childcare tends to also be expensive, student parents may be forced to trade-off between their enrollment level and their satisfaction with childcare. Subsidized, or reduced-cost, childcare is an important resource that may allow student parents to more fully access higher education and decrease the pressure to make a childcare-enrollment trade-off.

The purpose of this study was to identify critical childcare resources that student parents utilize that allow them to access higher education at varying levels, but also to make assumptions about parents unable to enroll due to barriers and/or lack of resources. This study sought to answer the following questions: 1) To what extent does subsidized childcare facilitate student parents' access to higher education? Is subsidized childcare a more important resource for some groups of 
students than for others?, and 2) Are student parents making childcare-enrollment trade-offs in order to pursue higher education? Are certain groups of students more vulnerable to making trade-offs?

A random sample of 750 student parents at Portland State University who had applied for Federal Financial Aid for the 2002-2003 school year were selected to receive a mail survey. After three mailings, 332 returned useable surveys were analyzed, which yielded a response rate of $44.8 \%$.

The results indicated that student parent Financial Aid applicants at PSU, $75 \%$ of whom are women, are using a variety of complex childcare arrangements and resources that allow them to access higher education. Student parents were more likely to be enrolled full-time than non-parents, but almost half indicated that they were not satisfied with their desired enrollment level. Student parents appear to be using different types of strategies to balance school, work, and family responsibilities. The strategies that students have available to them varies significantly by gender, marital status, class, and the age of their youngest child.

Many student parents who are resource poor were utilizing subsidized childcare. This was a critical resource that facilitated their access to higher education. 
THE EFFECTS OF SUBSIDIZED CHILDCARE ON STUDENT PARENTS' ACCESS TO HIGHER EDUCATION AT PORTLAND STATE UNIVERSITY

$$
\text { by }
$$

ELIZABETH DAWN CREACH

A thesis submitted in partial fulfillment of the requirements for the degree of

\author{
MASTER OF SCIENCE \\ in \\ SOCIOLOGY
}

Portland State University

2003 
This thesis is dedicated to my daughter, Tyler.

You are the purpose, driving force, and sunshine in my life every day. 


\section{ACKNOWLEDGMENTS}

This research would not have been possible without funding from the Portland State University President's Commission on the Status of Women.

I would like to sincerely thank the members of my thesis committee who have supported me through this process:

Daniel Sullivan

\section{Grant Farr}

I would also like to specially thank the chair of my thesis committee,

Johanna Brenner, for her generous guidance, patience, and mentoring.

This thesis would also not have been possible without the relentless support of : Jack M. Creach, Jr.

Linda L. Pouliot $\&$

John W. Rutherford, III 


\section{TABLE OF CONTENTS}

- Acknowledgments

- List of Tables

- Chapter I: Introduction 1

Literature Review 3

Research Questions $\quad 7$

- Chapter II: Methodology 8

Sample Characteristics $\quad 10$

Operational Definitions $\quad 11$

Hypotheses 16

- Chapter III: Findings 18

Who Are Student Parents at PSU? 18

Children, Childcare, and Costs 23

Enrollment Characteristics $\quad 32$

Hypotheses 37

Different Strategies for Different Students $\quad 59$

- Chapter IV: Conclusion 63

- References 68

- Appendix A: Cover Letter 70

- Appendix B: Survey Instrument 71

- Appendix C: Reminder Postcard 76 


\section{LIST OF TABLES}

Table 1: Selected Sample and Population Characteristics (\%)

Table 2: Selected Characteristics of Respondents and PSU Population (\%)

Table 3: Marital Status, Income, Hours Worked Per Week, and

Student Loan Debt for Total Sample, Males, \& Females

Table 4: Total Monthly Cost of Childcare by Age of Youngest Child,

Excluding Those with No Costs $(\$)$

Table 5: Types of Free or Reduced-Cost Childcare Utilized by Student Parents 26

Table 6: Types of Childcare for Youngest Child, by Age Group (\%)

Table 6.1: Types of Childcare for Youngest Child (ages 0-5), by Gender (\%) 28

Table 6.2: Primary Childcare Arrangement for Youngest Child, by Gender (\%) 29

Table 6.3: Primary Childcare Arrangement for Youngest Child, by Gender \& Marital Status (\%)

Table 7: Classes Missed Due to Problems with Childcare, by Gender (\%)

Table 7.1: Classes Missed due to Problems with Childcare, by Gender \& Marital Status (\%)

Table 8: Mean Number of Credit Hours, by Gender \&

Graduate/Undergraduate Status

Table 9: PT/FT Enrollment Status of Respondents and PSU Population (\%) 34

Table 10: Self-Reported Reasons for Taking Fewer Credit

Hours Than Desired (\%)

Table 11: Student Parents' Subjective Enrollment Status, by Gender (\%)

Table 11.1: Self-Reported Reasons for Taking Fewer Credit Hours Than Desired, by Gender (\%) 
Table 12: Student Parents' Subjective Enrollment Status, by Gender \&

Marital Status (\%)

Table 12.1: Self-Reported Reasons for Taking Fewer Credit Hours

Than Desired, by Gender \& Marital Status (\%)

Table 13: Student Parents Subjective and Objective Enrollment Status,

by Gender \& Marital Status (\%)

Table 13.1: Median Number of Enrolled Credit Hours, by

Subjective Enrollment Status, Gender, \& Marital Status (\%)

Table 14: Characteristics of Resource Poor and Non-Resource Poor

Student Parents

Table 15: The Importance of Subsidized Childcare

Table 16: Subjective Enrollment Status of Resource Poor Student Parents,

by Access to Subsidized Childcare (\%)

Table 17: Subjective Enrollment Status of Resource Poor Student Parents

Who Are Taking Fewer or More Credit Hours Than They Desire, by Access to Subsidized Childcare (\%)

Table 18: Subjective Enrollment Status of Resource Poor Student Parents, by Access to Subsidized Childcare \& Enrollment Status (\%)

Table 18.1: Resource Poor Student Parents' Median Enrolled Credit

Hours, by Access to Subsidized Childcare (\%)

Table 19: Females' Level of Satisfaction with Primary Childcare

Arrangement, by Full-Time \& Part-Time Status (\%)

Table 19.1: Females' Level of Satisfaction with Primary Childcare

Arrangement, by Enrollment Status \& Marital Status (\%)

Table 20: Full-Time Resource Poor Females' Level of Satisfaction with

Primary Childcare Arrangement, by Access to Subsidized Childcare (\%)

Table 20.1: Full-Time Resource Poor Females' Level of Satisfaction with

Primary Childcare Arrangement by Access to Subsidized Childcare \& Age of Child (\%) 


\section{INTRODUCTION}

This research explores the extent to which subsidized childcare has an effect on student parents' access to higher education at an urban university. Researchers have found that a key institutional barrier for parents pursuing higher education is a lack of access to quality and affordable childcare (CFITE, 2002). This is particularly true for women, who appear to make up an overwhelming majority of the student parent population (Fadale and Winter, 1991; Emlen, 1990). Because the gendered division of labor assigns women to be primarily responsible for childrearing and making childcare arrangements, women's access to higher education is greatly affected by the cost of childcare. Thus, childcare costs are a particularly gendered institutional barrier. Feminists have argued that the resistance to, and lack of support for, subsidized childcare stems from the traditional male breadwinner/female homemaker family structure, which is prevalent in both social norms and institutional structures (Abramovitz, 1988).

Childcare expenditures have also been shown to inhibit women's participation in the paid labor force, particularly for those with very young children (Maume, 1991). However, the extent to which the cost of childcare functions as a barrier to higher education is dependent on the amount and type of resources a particular student has available. Thus, there is stratified and unequal access to higher education. For women, access to higher education is a precursor to economic advancement and equal participation in the work force. Research has shown that women's increased earnings and labor force participation are indeed the 
result of their rising rates of participation in higher education (Blau, 1998).

Considering the persistent and strong correlation between educational attainment and socioeconomic status, there is reason to be concerned about stratified access to higher education; it perpetuates and reinforces gender, class, and race inequalities.

The cost of childcare is particularly difficult for low-income families. The U.S. Census Bureau reports that poor families consistently spend roughly three times more of their budget than non-poor families on child care costs (Smith, 2002). Furthermore, households that are headed by a female are much more likely to be poor. Social scientists have referred to this trend as the feminization of poverty, which refers to the "increasing tendency for poor populations in the United States to be composed of women" (Sapiro, 1999:481). The importance of higher education for low-income females cannot be understated. Research has shown that increased education leads to increased earnings and, for single mothers, allows for economic independence and higher levels of family well being (Gettell, Schehl, and Fereri, 1990; Corcoran and Loeb, 1999; Pavetti, 1999; Blau, 1998). Since it is likely that childcare costs are a formidable barrier to higher education for lowincome single women, it is also likely that access to subsidized childcare is a crucial resource that facilitates their ability to participate in higher education.

This research examines student parents currently enrolled in higher education at an urban university, Portland State University. By studying student parents already accessing higher education, we can observe what critical childcare resources they are utilizing and how these resources affect their ability to access 
higher education. Also, by observing the characteristics of parents who are enrolled, we can draw some conclusions about the childcare resources that facilitate different groups of parents' access to higher education and how the absence of those resources may act as barriers for parents who are unable to enroll.

\section{$\underline{\text { Literature Review }}$}

A review of the literature indicates that variation in credit hours among enrolled students in higher education is affected by marital status, age, race, income, work status, and the presence of children. In general, student parents are enrolled in fewer credit hours and are more likely to be enrolled part-time than are non-parents (Emlen, 1990; Stratton, O'Toole, and Wetzel, 2001).

Although gender does not seem to have an independent effect on credit hours, when we consider marital status, gender does play an important role. For example, Emlen (1990) found in a survey of Portland State University student parents that only $20 \%$ were men, and of them, $80 \%$ were married. Of the $80 \%$ of student parents that were women, only $42 \%$ were married. Findings such as these indicate that male student parents are two times more likely to have a partner available as a crucial resource while they participate in higher education. Women, on the other hand, are much more likely to be missing this resource which provides household income, support, and unpaid childcare.

Married student parents (or those with a partner who contributes to household income) are likely to have more monetary resources available to them from their partner's wage income. Unmarried student parents, a vast majority of 
whom are women, are also missing this important resource. Having income available from a working spouse/partner may allow student parents to work fewer hours (or not at all) and dedicate more time to their education. In a study of students enrolled in higher education, Perkins, Pitter, Howat, and Whitfield (1999) found that higher employment rates did decrease credit hours taken per term and thus lengthen the time to degree. They also found that women tended to have higher rates of employment than men. Similarly, Emlen (1990) found a strong inverse relationship between the number of hours worked per week and enrolled credit hours among student parents, with males working more hours per week than females.

Two other variables have been shown to affect enrolled credit hours. Age has been shown to have a significant impact on the enrollment status of students. In general, older students are much more likely to be enrolled part-time, but this is presumably due to their increased familial and work responsibilities (Stratton, et al., 2001). Race has also been shown to influence enrollment decisions, with Hispanics much more likely to be enrolled part-time (Stratton, et al., 2001).

\section{Childcare-Enrollment Trade-Offs}

In order to access higher education, all parents must make childcare arrangements, unless their children are in school or old enough to not require supervision. There are three types of resources that student parents could be utilizing in order to deal with their childcare arrangements: someone to provide 
childcare free of charge, sufficient income to pay for childcare, and/or subsidized childcare.

In terms of direct childcare resources, married or partnered student parents are more likely to have a person available for childcare at no cost. Similarly, student parents who have a family member or friend available to provide childcare free of charge possess an important resource that may allow them to more fully access higher education. However, many student parents may not have this critical resource available, due to a variety of reasons, and are forced to arrange for paid childcare. Childcare can be very expensive, especially for students forgoing wage income while they attend classes. For example, in Emlen's 1990 research $71 \%$ of student parents reported having difficulty paying for childcare while they attended Portland State University.

In response to both the high cost of childcare and the increased enrollment of women in higher education, subsidized on-campus childcare centers have been emerging on campuses across the nation. They tend to be high quality and relatively inexpensive. Research has shown the value of such centers for student parents in higher education. Fadale and Winter (1991) found that $81 \%$ of student parent respondents ( $95 \%$ of whom were women) said the availability of on-campus childcare was a very important decision to enroll in college and $60 \%$ said they would not be able to continue without access to on-campus childcare. On-campus centers have been shown to be a crucial facilitator for student parents' academic success (Fadale and Winter, 1991), and a necessity for taking full advantage of 
their educational experience (Gonchar, 1995). Student parents have also expressed enthusiasm about the quality of on-campus centers (Fadale and Winter, 1991). Two subsidized childcare centers are located on campus at PSU. Yet despite the demonstrated benefits of subsidized centers for student parents, there is limited availability and funding. At Portland State University there are long waiting lists for the on-campus subsidized childcare centers. At the time of this report, Helen Gordon Child Development Center had 327 families on the waiting list and the expected wait time was one year.

Even though student parents are enrolled in higher education, some may not be satisfied with their level of access. Emlen (1990) found that $47 \%$ of student parents were taking fewer credit hours than they would like, with $23 \%$ citing lack of childcare as the main reason. Furthermore, $41 \%$ said financial difficulties forced them to accept childcare arrangements that were less than satisfactory. This leads to a discussion of the "childcare-enrollment trade-offs" that some students may use to cope with childcare issues. Because low-quality childcare tends to also be less expensive, some student parents may be forced to place their child in a less than satisfactory environment in order to pursue their education. Or, they may reduce their number of credit hours in order to maintain their childcare quality. Either way this is a costly trade-off for the student parent.

However, given the opportunity for high quality care at a reduced cost childcare center, student parents can continue pursuing their education full time while not sacrificing their children's safety, development, and well-being. Student 
parents who lack other critical childcare resources would seem to be particularly at risk for making a childcare-enrollment trade-off. For example, Emlen (1990) found that unmarried student parents were more likely than married student parents to say that financial difficulties forced them to accept childcare arrangements that were less than satisfactory.

Other literature on low-income single mothers in the workforce also suggests that trade-offs may be occurring. Berger and Black (1992) found that lowincome single mothers who began receiving childcare subsidies tended to be much more satisfied with the quality of childcare they received. The quality of childcare they chose increased dramatically by objective measures as well. Findings such as these indicate that mothers, particularly low-income single mothers who pay fullcost for childcare, may be pressured to sacrifice the quality of care that their children receive because of financial difficulties. When given access to reducedcost childcare, their level of satisfaction increases substantially.

\section{Research Questions}

This review of the literature generated the following research questions:

1) To what extent does subsidized childcare facilitate student parents' access to higher education? Is subsidized childcare a more important resource for some groups of students than for others?

2) Are student parents making childcare-enrollment trade-offs in order to pursue higher education? Are certain groups of students more vulnerable to making tradeoffs? 


\section{Methodology}

\section{Research Strategy}

This research utilized self-administered mail surveys sent to a random sample of 750 student parents at Portland State University during the beginning of Spring Term 2003. This survey gathered information concerning student parents' gender and race, marital status, household structure, enrollment status, and childcare costs and arrangements. A quantitative approach was used to analyze the data.

The first survey mailing occurred at the beginning of April, and a reminder postcard was sent one week later. The second survey mailing occurred approximately three weeks after the initial mailing and was sent only to those who had not yet returned their survey. These steps, congruent with the Dillman method (1974), were taken to maximize the response rate. (See Appendix A for cover letter, and Appendix C for postcard.)

\section{Survey Instrument}

The survey instrument was constructed to gather a wide variety of information from student parents at PSU. The first section contained questions regarding all of students' childcare arrangements for their youngest child. Data was only collected for each respondent's youngest child in order to minimize the length of the survey and thus increase the response rate. For each childcare arrangement, 
respondents were asked about the number of hours spent per week, what the cost was, and their level of satisfaction.

Because childcare arrangements vary substantially by age, this section was divided between young children who had not yet started school (ages 0-5), and children who were enrolled in kindergarten through high school (ages 5-19).

The last section of the survey gathered more childcare information, such as students' total monthly cost for childcare, and how many classes they had missed during the previous term due to childcare issues. Finally, various enrollment and demographic information was collected. (See Appendix B)

Sample

Because the Registrar's Office does not collect information about whether or not students have children, the sample of student parents was drawn from the records of the Office of Student Financial Aid. This office maintains a database containing information on all students who have applied for Federal Financial Aid. In any given year, many more students apply for aid than actually have aid dispersed. During Winter Term 2003, 48\% of enrolled students at PSU had aid dispersed $(8,939$ of 18,368$)$.

The random sample is, therefore, composed of students who applied for 2002-2003 Federal Financial Aid, were enrolled in at least one credit during Winter Term $2003^{1}$, and who indicated they had a dependent child. In Spring Term 2003,

\footnotetext{
'We selected students who were enrolled for a least one credit during Winter Term so that (1) we would eliminate students who applied for Financial Aid but did not actually enroll at PSU, and (2) so that our list would contain the most valid mailing addresses.
} 
this query yielded 1,477 student parents, and a random sample of 750 was selected to receive the Student Parent Survey. Student parents who did not apply for Federal Financial Aid are not included in this sample.

Lola Lawson at Student Parent Services handled the address labels produced by the Financial Aid office so that respondents remained completely anonymous to the primary researcher. Surveys were returned in a postage-paid business reply envelope to the office of Student Parent Services and tracked. The primary researcher then case numbered and entered them into SPSS for data analysis.

After three mailings, 332 completed surveys were entered into SPSS and analyzed. Seven more surveys were returned but were not usable ${ }^{2}$, and two were returned due to old or incorrect addresses. This produced a total response rate of $44.8 \%(332 / 741)$.

\section{Sample Characteristics}

The Financial Aid Office provided some baseline data concerning the population of student parents who matched our search criteria. The sample of respondents did not differ from the population in significant ways. (See Table 1) Thus, we can be reasonably assured that the sample of student parents is representative and that a large response bias did not occur.

\footnotetext{
${ }^{2}$ Seven student parents returned blank surveys and indicated that their children were older (for example, graduated from high school) and did not need childcare so they felt the survey did not apply to them.
} 
Table 1: Selected Sample and Population Characteristics (\%)

\begin{tabular}{lll}
\hline & $\frac{\text { Sample }}{(n=332)}$ & $\frac{\text { Population }}{(N=1,477)}$ \\
\hline Female & 75.2 & 68.9 \\
Male & 24.8 & 31.1 \\
Married/Partnered & 62.3 & 64.3 \\
Single & 37.7 & 35.7 \\
Graduates/ & 33.1 & 31.8 \\
Undergraduates & 66.9 & 68.1 \\
Full-Time & & \\
Part-Time & 70.9 & 63.9 \\
\hline
\end{tabular}

Echoing past research findings, the vast majority of student parent respondents (75.2\%) were female. From data supplied by the Financial Aid Office, $68.9 \%$ of student parent Financial Aid applicants are female. $64.3 \%$ of the population is married, compared to $62.3 \%$ of the sample. $31.8 \%$ of the population and $33.1 \%$ of the sample are graduate students. Finally, $63.9 \%$ of the population and $70.9 \%$ of the sample are enrolled full-time.

\section{Operational Definitions}

"Access to Higher Education" This research will examine parents already enrolled at Portland State University; in essence they already have some access to higher education. Traditionally, researchers have studied access to higher education using a binary enrolled/not enrolled dependent variable. However, this dichotomy fails to take into account that there are varying levels of access among those enrolled, and at the same time ignores characteristics that contribute or detract from 
the rate of progress of different students (Bivin and Rooney, 1999). For example, students who are able to take more credit hours per term will complete their education in a timelier manner and reduce the costs associated with being a student, including tuition costs and forgone income. Furthermore, research has found that students who are enrolled for fewer credit hours are at a greater risk of dropping out and not finishing their degree (Okun, Benin, and Brandt-Williams, 1996). Thus, it is an advantage to be able to take more credit hours per term because it decreases the costs associated with higher education and increases the likelihood of degree completion.

Using a continuous credit hour variable or a dichotomous part-time/fulltime variable, however, does not take into account that some students prefer to be enrolled in school part-time. As we can imagine, particularly among nontraditional students who may be working full-time, the desired rate of progress through higher education varies. A "subjective enrollment status" variable was constructed to determine if student parents are taking their desired number of credit hours:

Q13. Which best describes your current enrollment status?

I am taking more credit hours than I would like. I am taking just as many credit hours as I would like. I am taking fewer credit hours than I would like.

Thus, two dependent variables are used to measure student parents' access to higher education--one objective, and one subjective indicator. 
"Subsidized Childcare" Subsidized childcare will be defined as free or reduced-cost childcare that is utilized while student parents attend classes, work, or study. This does not include school (K-12) or childcare that is provided free of charge by a spouse, partner, relative, or friend. Types of subsidized childcare include childcare scholarships, government programs that help pay childcare costs, reduced-cost or free before or after-school programs, and reduced-cost centers such as YMCA, Head Start, or the Helen Gordon Child Development Center and ASPSU childcare centers on-campus at PSU.

"Low-Income" A dichotomous low-income variable was constructed based on respondents reported gross yearly household income and household size. Lowincome student parents were defined as those whose income level was at or below $200 \%$ of the U.S. Census Bureau 2002 Poverty Threshold for each corresponding household size. (www.census.gove/hhes/poverty/threshld/thresh02.html).

The federal government's poverty measurement has been extensively criticized for failing to accurately represent what poor families need to make ends meet. For example, the poverty threshold does not take into account the cost of childcare. A revised measure developed in 1992, yielded a poverty threshold $45 \%$ higher than the official one. (Mishel, Bernstein, and Boushey, 2002-2003: 320). Because the poverty thresholds are so low, it seemed fairly certain that families living at or slightly above the poverty threshold would be unlikely to access higher education, given the costs involved (tuition, books, etc.) It seemed reasonable, therefore, to set the threshold of "low-income" higher than the official poverty line. The level of 
$200 \%$ of the official poverty line was selected for two reasons. First, from the researcher's own experience, even parents with household incomes well above the poverty line experience difficulties paying for childcare. For example, a single mother with one child with a gross yearly income at $200 \%$ of the poverty line would have a gross household income of $\$ 24,800$. If she had to pay for full-time center-based childcare for a preschool age child, which averages $\$ 515 /$ month $^{3}$ in the Portland metropolitan area, this would represent $25 \%$ of her gross monthly income.

Secondly, most households in the United States have incomes above $200 \%$ of the official poverty line--in 2000 , about one third of the population were living in households at or below this threshold. (Mishel, Bernstein, and Boushey, 20022003: 327 ) Thus, although $200 \%$ of the poverty line is well above poverty, it captures households at the low end of the income distribution that would have difficulty paying for childcare.

"Resource poor" This refers to childcare resources. There are three primary types of resources that student parents might be utilizing in order to meet their childcare needs--free childcare, sufficient income to pay for childcare, and/or subsidized childcare. In order to define "resource poor," the first two of these variables were considered. Student parents who have a higher income level are less likely to struggle with the cost of childcare, and so are not considered resource

${ }^{3}$ Data concerning market-based childcare rates is from the 2002 median market rate for a preschool-age child attending full-time at a childcare center in the Portland metropolitan area. (http://www.hhs.oregonstate.edu/familypolicy/occrp/publications/2002-Market-Rate-Study.pdf) 
poor. Similarly, student parents who reported having no monthly childcare costs either have older children who do not require childcare or have someone available to provide all of their childcare free of charge. These students are also not considered resource poor. Thus, resource poor student parents are those who are low income and who reported having monthly childcare costs.

Resource Poor:

1) At or below $200 \%$ of poverty threshold and

2) Reported having childcare costs
Non-Resource Poor:

1) Above $200 \%$ of poverty threshold

2) Reported having no childcare costs

"Satisfaction with Childcare" A global four-point Lickert scale was used to assess student parents' satisfaction with each childcare arrangement for their youngest child. For purpose of this research, we will rely on the student parents' satisfaction with their primary childcare arrangement, as determined by the arrangement in which the child spends the most hours per week. Childcare does not include school (kindergarten through high school).

Satisfaction with childcare is a difficult concept to measure. We can speculate that parents might not want to admit to themselves or others that they are dissatisfied with the childcare they are utilizing. Also, there are many different components of satisfaction, for example, the cleanliness or cost, the provider or curriculum, or safety issues. One weakness of the global measure is that it does not distinguish why parents are dissatisfied. 
Despite these limitations, the global satisfaction question was used instead of a more complex measure because of 1) the need to limit the size of the survey, and 2) Emlen (1990) and Berger and Black (1992) had used a similar question and found sufficient variation in parents' levels of satisfaction.

\section{$\underline{\text { Hypotheses }}$}

The gendered division of childcare labor places the burden of childcare arrangements and costs disproportionately on women. Furthermore, female student parents are much more likely than male student parents to be unmarried and lowincome. Because females face more barriers and have fewer resources available to them, they are more likely to have their access to higher education impeded.

Hypothesis \#1: Female student parents will be more likely than male student parents to indicate that they are enrolled in fewer credit hours than they desire.

Student parents who are lacking and/or missing other critical childcare resources, such as someone to provide childcare free or charge or a sufficient income level, are more likely to require a supplemental childcare resource in order to access higher education. Student parents who are resource poor, but have access to this resource (subsidized childcare), will be able to access higher education more fully than resource poor student parents who do not have this resource.

Hypothesis \#2: Student parents who are resource poor and do not have access to subsidized childcare will be more likely to report taking fewer credit hours than they would like compared to resource poor parents with access to subsidized childcare. 
Because childcare burdens are disproportionately placed on women, they are more likely to be forced to make a trade-off between their satisfaction with childcare and their enrollment in higher education.

Hypothesis \#3: Female student parents who are enrolled full-time will be less satisfied with their primary childcare arrangement than female student parents who are enrolled part-time.

There is evidence in the literature to suggest that low-income women who pay full-price for childcare are less satisfied with their childcare than when their childcare expenditures are reduced by childcare subsidies. When given the opportunity to reduce their childcare expenses, these women chose higher quality childcare for their children. In other words, subsidized childcare will reduce the likelihood of making a childcare satisfaction trade-off among students most likely to be pressured to do so.

Hypothesis \#4: Full-time resource-poor female student parents who have access to subsidized childcare will be more satisfied with their primary childcare arrangement than full-time resource-poor female student parents who do not have access to subsidized childcare. 


\section{FINDINGS}

\section{Who Are Student Parents at PSU?}

The sample of student parent respondents $(N=332)$ differed from the total

PSU student population ${ }^{4}$ in important ways. (See Table 2)

Table 2: Selected Characteristics of Respondents and PSU Population (\%)

\begin{tabular}{|c|c|c|}
\hline & $\frac{\text { Student Parent Respondents }}{(n=332)}$ & $\frac{\text { PSU Population }}{(N=18,368)}$ \\
\hline Female & 75.2 & 55.5 \\
\hline Male & 24.8 & 44.5 \\
\hline Mean Age (in years) & 32.62 & 28.5 \\
\hline Race/Ethnicity & $\begin{array}{l}\text { White }=82.6 \\
\text { Black }=4.9 \\
\text { Hispanic }=4.9 \\
\text { Asian }=3.4 \\
\text { Multi-Racial }=3.7 \\
\text { Native American }=0.3\end{array}$ & $\begin{array}{l}\text { White }=66.8 \\
\text { Black }=3.0 \\
\text { Hispanic }=3.9 \\
\text { Asian }=9.0 \\
\text { Multi-Racial }=9.6 \\
\text { Native American }=1.2\end{array}$ \\
\hline $\begin{array}{l}\text { Undergraduates } \\
\text { Graduates }\end{array}$ & $\begin{array}{l}66.5 \\
33.6\end{array}$ & $\begin{array}{l}75.4 \\
24.6\end{array}$ \\
\hline $\begin{array}{l}\text { Full-Time } \\
\text { Part-Time }\end{array}$ & $\begin{array}{l}70.9 \\
29.1\end{array}$ & $\begin{array}{l}57.1 \\
42.9\end{array}$ \\
\hline
\end{tabular}

Perhaps the most striking difference between student parents and the PSU population is the gender composition. The sample was $75.2 \%$ female and $24.8 \%$ male, which reflects the gendered nature of the student parent population found in

\footnotetext{
${ }^{4}$ All data concerning the total Portland State University population comes from the Spring Term Factbook 2003 (4th week), published by the Office of Institutional Research and Planning. Institutional averages include student parents in their figures.
} 
previous research (Emlen, 1990; Fadale and Winter, 1991). The total PSU student population was $44.5 \%$ male and $55.5 \%$ female. Also reflecting previous research findings, the sample of student parents tended to be older than the PSU population. The mean age of student parent respondents was 32.62 , with a range from 19 to 56 years of age and a standard deviation of 7.4 years. For the total PSU population the average age was 28.5 years.

The race/ethnicity of the sample of student parents was characterized by being less racially and ethnically diverse than the PSU student population. The vast majority ( $82.6 \%$ ) reported being White/Caucasian, 4.9\% Hispanic/Latino/a, 4.9\% Black, 3.7\% Multi-Racial, 3.4\% Asian/Pacific Islander, and $0.3 \%$ Native American. The race/ethnicity of the total PSU population was $66.8 \%$ white, $9 \%$ Asian/ Pacific Islander, 5.4\% International students, 3.9\% Hispanic/Latino/a, 3\% Black, 1.2\% Native American, 1.1\% Multi-Racial, and 9.6\% declined to respond. Student parents tend to be juniors, seniors, and graduate students. A higher percentage of student parents are graduate students than the total PSU student population. Almost two-thirds $(66.5 \%)$ of respondents were pursuing their undergraduate degree and $33.6 \%$ were graduate students. In the PSU population, $75.4 \%$ of students are undergraduates and $24.6 \%$ are graduates students. $34.8 \%$ of the sample was seniors, $22 \%$ juniors, $7.6 \%$ sophomores, and only $2.1 \%$ were firstyear students. One-quarter (24.4\%) were in a Master's degree program, and 3.4\% were Doctoral students. 
Next, we will examine more demographic characteristics of the student parent respondents. (See Table 3)

Table 3: Marital Status, Income, Hours Worked Per Week, and Student Loan Debt for Total Sample, Males, \& Females

\begin{tabular}{|c|c|c|c|c|}
\hline & $\begin{array}{l}\text { Sample } \\
(N=332)\end{array}$ & $\begin{array}{l}\text { Males } \\
(n=82)\end{array}$ & $\begin{array}{l}\text { Females } \\
(n=248)\end{array}$ & $X^{2}$ \\
\hline Marital Status (\%) & & & & $27.40^{* *}$ \\
\hline Married & 59.0 & 86.6 & 54.3 & \\
\hline Single & 41.0 & 13.4 & 45.7 & \\
\hline Income (\%) & & & & 8.34 \\
\hline$\$ 50,000$ or more & 25.1 & 32.9 & 22.3 & \\
\hline$\$ 25,000-\$ 49,999$ & 34.2 & 34.3 & 33.5 & \\
\hline$<\$ 25,000$ & 40.7 & 32.9 & 43.4 & \\
\hline$<\$ 10,000$ & 12.9 & 6.1 & 15.3 & \\
\hline Sources of Income $(\%)$ & & & & $\mathrm{N} / \mathrm{A}$ \\
\hline Own employment & 60.5 & 70.7 & 57.1 & \\
\hline Spouse/partner & 50.5 & 58.5 & 47.8 & \\
\hline Student loans & 77.2 & 70.7 & 79.4 & \\
\hline Grants & 37.4 & 29.3 & 40.1 & \\
\hline Scholarships & 17.6 & 12.2 & 19.4 & \\
\hline Work Study & 3.6 & 1.2 & 4.5 & \\
\hline Child support & 17.3 & 0 & 23.1 & \\
\hline Relatives or friends & 9.7 & 4.9 & 11.3 & \\
\hline Food Stamps & 19.1 & 9.8 & 22.3 & \\
\hline Government & 4.6 & 4.9 & 4.5 & \\
\hline Pension, Social Security, etc & 3.3 & 2.4 & 3.6 & \\
\hline Hours Worked Per Week & & & & $13.11^{1 * *}$ \\
\hline Mean & 16.8 & 22.6 & 14.9 & \\
\hline$\%$ Who do not work & 36.3 & 28.4 & 38.6 & \\
\hline Student Loan Debt (\%) & & & & $11.64^{*}$ \\
\hline$\$ 0$ & 9.8 & 11.0 & 9.4 & \\
\hline$<\$ 10,000$ & 28.1 & 40.2 & 24.5 & \\
\hline$\$ 10,000-\$ 19,999$ & 30.1 & 24.4 & 31.8 & \\
\hline$\$ 20,000-\$ 34,999$ & 29.3 & 19.5 & 32.7 & \\
\hline$\$ 35,000$ or more & 12.5 & 15.8 & 11.0 & \\
\hline
\end{tabular}

$N=330 \quad * p<.05$

${ }^{1} F$ statistic $\quad{ }^{* *} p<.01$ 
Most student parents (59.0\%) reported being married, with 17\% divorced and another 18.2\% single. As reported in previous research (Emlen, 1990), female student parents are much more likely to be single, divorced, or widowed than their male counter parts. Clearly, female student parents are much less likely to have the support of a partner while attending higher education. The living arrangements of student parent respondents show that $63.8 \%$ are living with a spouse or partner, $27.1 \%$ live alone, $5.5 \%$ live with parents or other relation, and $2.7 \%$ live with roommates.

The respondents' gross yearly household income was quite varied, although most student parents live on a very modest income. One quarter $(25.1 \%)$ had incomes of $\$ 50,000$ or above. However, most respondents $(40.7 \%)$ had yearly incomes below $\$ 25,000$, and $12.9 \%$ were below $\$ 10,000$. As expected, female student parents tended to have lower gross household incomes, although this failed to achieve statistical significance. Almost one-third (32.9\%) of males and $22.3 \%$ of females reported incomes over $\$ 50,000$. However, $15.3 \%$ of females and only $6.1 \%$ of males reported incomes less than $\$ 10,000$. Student parents reported receiving income from a variety of sources.

Of the total sample, the average number of hours worked per week is 16.8 ( $s d=16.76$ hours). While many student parents do not work (36.3\%), those who do typically work many hours on top of their school responsibilities. When we exclude those who do not work, the mean number of hours worked is 26.38 , with a standard 
deviation of 13.71 hours. One-third (33.3\%) of student parents who work put in 40 or more hours per week.

Male student parents tend to have high rates of employment and work more hours per week than female student parents. Males reported working an average of 22.6 hours per week and females reported working 14.97 hours. $38.6 \%$ of females and $28.4 \%$ of males do not work any hours per week.

Most student parents are incurring large amounts of student loan debt, but females are much more likely to be incurring loan debt and also incur higher amounts than males. For example, $40.2 \%$ of males have less than $\$ 10,000$ in loan debt, only $24.5 \%$ of females do. We can generalize this trend to the larger population of student parents.

Despite the difficulties of balancing school, work, and family responsibilities, student parents are performing very well academically. $32.5 \%$ reported a 3.76 to 4.9 grade point average (GPA). Another $47.9 \%$ reported a 3.1 to 3.75 GPA. Females tended to have higher grades, with $35 \%$ of females and $25.6 \%$ of males having a 3.76-4.00 grade point average $\left(X^{2}=4.14, p=.388\right)$.

Student parents also tend to be quite determined when it comes to achieving their educational goals. $66.1 \%$ felt "very certain" about reaching their educational goals, and another $27.5 \%$ felt "somewhat certain." However, $6.4 \%$ felt "somewhat" or "very uncertain" about being able to reach their goals. Females tended to feel less certain about achieving their educational goals, although this 
failed to achieve statistical significance $\left(X^{2}=5.43, p=.143\right) .75 .3 \%$ of males and $62.7 \%$ of females felt "very certain" about achieving their educational goals.

\section{Children, Childcare, and Costs}

Half (49.5\%) of student parent respondents reported having one child. Another $32.3 \%$ had two children, $12.7 \%$ had three, and $5.1 \%$ had four or more children.

The majority of student parent respondents have very young children; $83 \%$ have a child under the age of eleven, and $90 \%$ have a child under the age of 14 . The majority $(62.3 \%)$ have children ages zero through five who have not yet started kindergarten. $13.3 \%$ of these student parents have children under one year of age, and the most frequent age of the youngest child was three (22.2\%). A substantial minority $(37.7 \%)$ had children in kindergarten through high school. $65.2 \%$ of these student parents have children ages five through eleven.

The Cost of Childcare

The total average monthly childcare cost for all respondents was $\$ 201.20$ $(s d=\$ 271.97)$. However, a surprisingly high $42.8 \%(n=140)$ of student parents reported having no monthly childcare costs. This differs substantially from the last major survey of PSU student parents, where only $16 \%$ reported having no childcare costs (Emlen, 1991). When we exclude students who have no childcare costs, the average monthly cost is $\$ 351.84$ ( $s d=\$ 276.34$ ). One-quarter ( $24.2 \%$ ) of student parents who have childcare costs pay more than $\$ 500.00$ per month. This data 
indicates that many student parents are finding ways to avoid paying for childcare, however, among those who use paid providers, childcare costs are typically high.

As Table 4 illustrates, student parents who have young children (ages infant through five, who have not yet started kindergarten, $n=207$ ) have a much greater childcare need, and thus higher childcare costs.

Table 4: Total Monthly Cost of Childcare by Age of Youngest Child, Excluding Those with No Costs $(\$)^{1 *}$

\begin{tabular}{llll}
\hline & $\begin{array}{lll}\text { Total } \\
(N=187)\end{array}$ & $\begin{array}{l}\text { School-Age Child } \\
\text { (age 5-19) } \\
(n=48)\end{array}$ & $\begin{array}{l}\frac{\text { Child }}{\text { in school }} \text { yet } \\
\text { (age 0-5) }\end{array}$ \\
\hline Mean & 351.84 & 171.89 & 415.73 \\
Standard Deviation & 276.34 & 139.82 & 284.84 \\
Median & 300.00 & 100.00 & 355.00 \\
\hline$N=187$ & & \\
${ }^{*} F=32.99(p<.01)$ & & \\
${ }^{1} 42.8 \%(n=140)$ of all respondents reported zero monthly childcare costs.
\end{tabular}

The average monthly childcare cost for students with young children is $\$ 278.50(s d=\$ 304.34)$. In this group, 33\% $(n=68)$ of student parents reported having no monthly childcare costs. When we exclude those with no childcare costs, the average monthly cost is $\$ 415.73(s d=\$ 284.84)$, and the median is $\$ 355.00$. Almost one third (31.2\%) of students with childcare costs and young children pay more than $\$ 500.00$ per month for childcare, and $11.2 \%$ pay $\$ 800.00$ or more per month. We can see quite a bit of variation in monthly childcare expenditures among student parents who have young children. Approximately onethird of students whose youngest child has not yet started school have no childcare costs, while approximately another one-third pay $\$ 500.00$ or more per month. 
Student parents whose youngest child was school age (ages five through nineteen, $n=121)$ reported paying an average of $\$ 69.62(s d=\$ 122.47)$ per month for childcare. However, $59.5 \%(n=72)$ of this group reported having no childcare costs. When we exclude those with no childcare costs, the average cost was $\$ 171.89$, with a median of $\$ 100.00(s d=\$ 139.82) .20 .2 \%$ pay $\$ 300.00$ or more per month, and $6 \%$ pay $\$ 450.000$ or more per month.

There is also quite a bit of variation among student parents with school-age children; a majority of this group has no childcare costs, yet among those who do, childcare costs are still fairly high. However, it is clear that student parents with younger children have much greater childcare costs, and a majority $(63.7 \%)$ of student parents reported having a child not yet school age.

\section{Childcare Resources}

Student parents reported utilizing a variety of resources to meet their childcare needs. Many students (57.7\%) have a spouse or partner who provides childcare. In Emlen's 1990 survey, only 27\% reported that their spouse or partner provided childcare. In all, $66.8 \%$ of the student parent sample reported having a spouse, partner, friend, or relative who provides some or all of their childcare free of charge. However, only $34.1 \%$ of student parents' have their primary childcare arrangement (most hours per week) free of charge.

For student parents who are forced to arrange for paid childcare, subsidies are another type of childcare resource that eases the burden of childcare costs. 
However, only a small portion of the sample reported having access to any type of subsidized childcare. (See Table 5)

Table 5: Types of Free or Reduced-Cost Childcare Utilized by Student Parents

\begin{tabular}{lc}
\hline Resource & $\begin{array}{c}\text { \% Who have this type } \\
\text { of resource }\end{array}$ \\
\hline Spouse, partner, friend, or relative & 66.8 \\
\hline On-campus subsidized childcare center & 7.8 \\
Other reduced-cost childcare center & 2.7 \\
Childcare scholarship $^{\text {Free or reduced cost before or after-school program }}$ & 4.6 \\
Help from government $^{\text {Total who use subsidized childcare }}{ }^{1}$ & 3.9 \\
\hline
\end{tabular}

$N=332$

I Subsidized childcare does not include school or childcare provided free of charge by a spouse, partner, friend, or relative.

A very small percentage (3.6\%) reported having help from the government for childcare costs, and $4.6 \%$ reported receiving a childcare scholarship (such as The Jim Sells Award). Surprisingly, only 7.8\% $(n=26)$ reported utilizing either of the on-campus subsidized childcare centers at PSU. Some students $(2.7 \%)$ were using another type of reduced-cost childcare center. $3.9 \%$ reported utilizing a free or reduced-cost before or after-school program. In all, only $17.1 \%(n=56)$ reported having some form of reduced-cost, sliding scale, and/or subsidized daycare. ${ }^{5}$ Among those with childcare costs, $28.6 \%$ are utilizing some type of subsidized childcare.

\footnotetext{
${ }^{5} 17.1 \%$ reported having any type of reduced-cost, sliding scale, or subsidized childcare. This includes the two childcare centers on campus (Helen Gordon CDC and ASPSU), and other programs such as YMCA, Head Start, and before or after-school programs.
} 


\section{Childcare Arrangements}

As Table 6 displays, student parents reported making a variety of childcare arrangements in order to meet their childcare needs.

Table 6: Types of Childcare for Youngest Child, by Age Group (\%)

\begin{tabular}{|c|c|c|}
\hline & $\frac{\text { School-age child }}{(n=125)}$ & $\frac{\text { Young child not yet }}{\text { in school }}(n=207)$ \\
\hline$\overline{\text { Unpaid spouse or partner }}$ & 42.6 & 57.7 \\
\hline Unpaid relative & 38.9 & 32.7 \\
\hline Childcare center, preschool & N/A & 41.5 \\
\hline Paid relative & 16.7 & 11.5 \\
\hline Paid non-relative $^{2}$ & 22.2 & 25.6 \\
\hline Before or after-school program & 25.2 & N/A \\
\hline Self-care & 46.6 & N/A \\
\hline
\end{tabular}

$N=332$

${ }^{1}$ This does not equal $100 \%$ because student parents often utilize more than one type of care.

${ }^{2}$ Paid non-relatives are typically referred to as family day care homes.

For student parents whose youngest child had not started school $(n=207)$, $57.7 \%$ use an unpaid spouse or partner, $32.7 \%$ use an unpaid relative, $11.5 \%$ use a paid relative, and $25.6 \%$ use a paid non-relative (such as a family daycare home). Many students ( $41.5 \%$ ) use a childcare center, preschool, or nursery. Of those who use a childcare center ( $n=85), 31 \%$ use one of the reduced-cost centers on campus at PSU, and $10.7 \%$ use another reduced-cost or sliding-scale center, such as YMCA or Head Start. Half of students who use center-based care use a full-cost center.

For student parents whose youngest child was in school $(n=125), 25.2 \%$ are using a before school or after school program. Almost one third (31\%) of these children attend a reduced-cost program, and $13.8 \%$ were in a free program. $42.6 \%$ use an unpaid spouse or partner, and $38.9 \%$ used an unpaid relative. $16.7 \%$ use a 
paid relative, and $22.2 \%$ used a paid non-relative. $46.6 \%$ of these children are caring for themselves while student parents attend work or school.

As Table 6.1 illustrates, the type of childcare that male and female student parents utilize varies substantially, with males being much more likely to have their spouse or partner available to provide unpaid childcare.

Table 6.1: Types of Childcare for Youngest Child (ages 0-5), by Gender (\%)

\begin{tabular}{|c|c|c|}
\hline & $\frac{\text { Males }}{(n=69)}$ & $\frac{\text { Females }}{(n=137)}$ \\
\hline Unpaid spouse or partner & 70.2 & 50.5 \\
\hline Unpaid relative & 24.6 & 37.4 \\
\hline Childcare center, preschool & 23.2 & 50.4 \\
\hline Paid relative & 10.5 & 12.1 \\
\hline Paid non-relative $^{2}$ & 14.0 & 33.2 \\
\hline Self-care & 0 & 0 \\
\hline
\end{tabular}

$N=206$

${ }^{1}$ This does not equal $100 \%$ because student parents often utilize more than one type of care.

${ }^{2}$ Paid non-relatives are typically referred to as family day care homes.

Among female student parents whose youngest child has not yet started kindergarten ( $n=137), 50.5 \%$ use an unpaid spouse or partner, $50.4 \%$ use a childcare center, preschool, or nursery, $37.4 \%$ use an unpaid relative, $12.1 \%$ use a paid relative, and $33.2 \%$ use a paid non-relative. When we look at male student parents whose youngest child has not yet started kindergarten $(n=69)$, we find a much different picture. The vast majority (70.2\%) use an unpaid spouse or partner, $23.2 \%$ use a childcare center, preschool, or nursery, $24.6 \%$ use an unpaid relative, $10.5 \%$ use a paid relative, and $14 \%$ use a paid non-relative. 
As Table 6.2 clearly demonstrates, males and females are also utilizing very different types of childcare for their primary childcare arrangement. ${ }^{6}$

Table 6.2: Primary Childcare Arrangement for Youngest Child, by Gender (\%)*

\begin{tabular}{lcl}
\hline & $\underline{\text { Males }}$ & $\underline{\text { Females }}$ \\
& $(n=80)$ & $(n=235)$ \\
\hline Unpaid spouse, partner, or relative & 53.8 & 27.7 \\
Paid relative or non-relative & 13.8 & 16.6 \\
Both paid and unpaid equally & 3.8 & 17.2 \\
Full-priced childcare center & 15.0 & 12.8 \\
Reduced-cost childcare center & 1.3 & 11.9 \\
Full-cost after-school program & 5.0 & 4.3 \\
Reduced-cost after-school program & 1.3 & 4.3 \\
Self-care & 6.3 & 15.3 \\
\hline
\end{tabular}

$N=315$

$* X^{2}=26.28(p<.01)$

More than half $(53.8 \%)$ of males have their unpaid spouse, partner, or relative as their primary childcare provider while they attend school, work, and study. Only $27.7 \%$ of females utilize an unpaid spouse, partner, or relative as their primary childcare arrangement. The significance of this finding is that female student parents are much more likely to have greater childcare costs, while many male student parents receive their childcare free of charge. In fact, $39.5 \%$ of females reported having no monthly childcare costs, while $52.4 \%$ of males reported the same.

Table 6.3 examines students' primary childcare arrangement by gender and marital status. Since the vast majority of male student parents are married or

\footnotetext{
${ }^{6}$ Student parents' primary childcare arrangement is determined by the provider where the youngest child spends the most hours per week, not including school.
} 
partnered $(86.6 \%)$, single males $(n=11)$ are excluded from this table. As expected, married/partnered males are the most likely to have their primary childcare arrangement free of charge. Single females are the least likely to have their primary childcare arrangement be free of charge, but are also the most likely to be utilizing subsidized childcare.

Table 6.3: Primary Childcare Arrangement for Youngest Child, by Gender \& Marital Status $(\%)^{i *}$

\begin{tabular}{|c|c|c|c|}
\hline & $\begin{array}{l}\frac{\text { Married }}{\text { Males }} \\
(n=69)\end{array}$ & $\frac{\frac{\text { Married }}{\text { Females }}}{(n=127)}$ & $\begin{array}{l}\frac{\text { Single }}{\text { Females }} \\
\frac{(n=107)}{}\end{array}$ \\
\hline Unpaid spouse, partner, or relative & 55.1 & 34.6 & 19.6 \\
\hline Paid relative or non-relative & 14.5 & 13.4 & 20.6 \\
\hline Both paid and unpaid equally & 4.3 & 9.4 & 4.7 \\
\hline Full-priced childcare center & 15.9 & 12.6 & 13.1 \\
\hline Reduced-cost childcare center & 1.4 & 10.2 & 14.0 \\
\hline Full-cost after-school program & 4.3 & 1.6 & 7.5 \\
\hline Reduced-cost after-school program & 0 & 3.1 & 5.6 \\
\hline Self-care & 4.3 & 15.0 & 15.0 \\
\hline
\end{tabular}

Again, more than half (55.1\%) of married males have an unpaid spouse, partner, or relative as their primary childcare arrangement, while only $34.6 \%$ of married females and $19.6 \%$ of single females do so. Only $14.0 \%$ of single females, $10.2 \%$ of married females, and $1.4 \%$ of married men are utilizing a subsidized childcare center as their primary childcare arrangement. Single females are also the most likely to be utilizing a free or reduced-cost before or after-school program. This suggests that single females, likely to be missing other critical childcare resources, gain the most benefit from subsidized childcare. 
Missed Classes Due to Childcare Problems

One of the difficulties of being a student parent is dealing with childcare when children become ill. Childcare facilities will not care for sick children, and often students are forced to miss class because they have no alternative care providers. During the ten-week winter term of $2003,31.1 \%$ of respondents missed one or two classes, $14 \%$ missed three or four classes, and $6.7 \%$ missed five or more classes due to childcare issues. However, $48.2 \%$ of reported that they did not miss any classes due to childcare issues.

As Table 7 indicates, female student parents are much more likely than males to miss class due to childcare issues.

Table 7: Classes Missed Due to Problems with Childcare, by Gender (\%)*

\begin{tabular}{lll}
\hline & Males & $\frac{\text { Females }}{(n=245)}$ \\
\hline No classes & 59.3 & 44.5 \\
One or two classes & 29.6 & 39.4 \\
Three or four classes & 7.4 & 16.3 \\
Five or more classes & 3.7 & 7.8 \\
\hline
\end{tabular}
$N=326$ $* X^{2}=7.73$ ( $\left.p=.052\right)$

The majority $(59.3 \%)$ of males, compared to $44.5 \%$ of females, reported missing no classes. However, $16.3 \%$ of females missed three or four classes while only $7.4 \%$ of males reported the same. These results were statistically significant. When we consider marital status, we find that both married and single females are more likely to miss class than married males. (See Table 7.1) 
Table 7.1: Classes Missed Due to Problems with Childcare, by Gender \& Marital Status $(\%)$

\begin{tabular}{lccc}
\hline & Married Males & $\frac{\text { Married Females }}{(n=133)}$ & $\frac{\text { Single Females }}{(n=111)}$ \\
\hline No classes & 62.9 & 47.4 & 40.5 \\
One or two classes & 25.7 & 28.6 & 35.1 \\
Three or four classes & 7.1 & 15.8 & 17.1 \\
Five or more classes & 4.3 & 8.3 & 7.2 \\
\hline
\end{tabular}

$N=314$

$X^{2}=10.32(p=.112)$

\section{Satisfaction with Childcare}

Most student parents (60.1\%) reported being "very satisfied" with their primary childcare arrangement. Another $32.4 \%$ said they were "somewhat satisfied," $6.2 \%$ said they were "somewhat concerned," and only $1.3 \%$ said they were "very concerned."

When we look at how gender plays a role, we find that male student parents in the sample tend to be more satisfied with their primary arrangement, but this failed to achieve statistical significance $\left(X^{2}=3.19, p=.203\right) 67.5 \%$ of males and $57.7 \%$ of females reported being "very satisfied." $28.6 \%$ of males and $33.5 \%$ of females reported being "somewhat satisfied." $3.9 \%$ of males and $8.8 \%$ of females reported being "somewhat" or "very concerned."

\section{Enrollment Characteristics}

Almost two-thirds (66.5\%) of student parent respondents were pursuing their undergraduate degree and $33.6 \%$ were graduate students. For undergraduates $(n=214)$, the mean number of enrolled credit hours was $12.34(s d=4.29)$ and the mode was 12. For graduate students $(n=107)$ the mean was $9.62(s d=4.95)$, and the 
mode was 9. The institutional average for all undergraduate students at Portland State University in the fourth week of spring term 2003 was 11.2. For graduates, the average was 8.4. Contrary to previous research findings, student parents at PSU tend to be enrolled in slightly more credit hours than the average student.

As Table 8 indicates, female student parents are taking approximately the same credit hours as male student parents and are actually enrolled in slightly more credit hours than non-parents at PSU. When we look at the full-time and part-time status of student parents, we find that females are actually more likely to be enrolled full time, but this failed to achieve statistical significance $\left(X^{2}=.742\right.$, $p=.243)$.

Table 8: Mean Number of Credit Hours, by Gender \& Graduate/Undergraduate Status

\begin{tabular}{|c|c|c|c|}
\hline & $\begin{array}{l}\text { Males } \\
(n=81)\end{array}$ & $\begin{array}{l}\text { Females } \\
(n=243)\end{array}$ & $\frac{\text { PSU Population }}{(N=18,368)}$ \\
\hline Undergraduates & 12.76 & 12.21 & 11.2 \\
\hline Graduates & 9.25 & 9.69 & 8.4 \\
\hline$\%$ Enrolled full-time & 67.1 & 72.1 & 57.1 \\
\hline
\end{tabular}

When we look at undergraduates only, females average 12.21 and males average 12.76 credits $(F=.605, p=.438)$. For graduate students, females average 9.69 and males average 9.25 credits $(F=.200, p=.656)$.

If we consider the entire sample of respondents, $50.3 \%$ are full time undergraduates and $17.4 \%$ are part-time undergraduates. ${ }^{7} 20.6 \%$ are full-time

\footnotetext{
${ }^{7}$ Full-time status for undergraduate students is 12 or more credit hours, and for graduates is 9 or more. Part-time for undergraduates is 11 credits or fewer, and for graduates is 8 credits or fewer
} 
graduate students and $11.7 \%$ are part-time. As Table 9 indicates, student parent respondents, both undergraduate and graduate, are more likely than other students at PSU to be enrolled full-time.

Table 9: PT/FT Enrollment Status of Respondents and PSU Population (\%)

\begin{tabular}{llc}
\hline & $\frac{\text { Sample }}{(N=332)}$ & $\frac{\text { PSU }}{(N=18,368)}$ \\
\hline Full-Time Undergraduates & 74.3 & 62.2 \\
Part-Time Undergraduates & 25.7 & 37.8 \\
\hline Full-Time Graduates & 63.7 & 41.7 \\
Part-Time Graduates & 36.3 & 58.3 \\
\hline
\end{tabular}

For undergraduates, $74.3 \%$ are full-time and $25.7 \%$ are part-time. Among the total PSU undergraduate population, $62.2 \%$ are full-time and $37.8 \%$ are parttime. $63.7 \%$ of respondents who are graduates are enrolled full-time and $36.3 \%$ are part-time. For the total PSU graduate population, $41.7 \%$ are full-time and $58.3 \%$ part-time.

Subjective Enrollment Status

When student parents were asked about their desired enrollment status, $53.4 \%$ reported taking just as many credit hours as they would like. However, almost half of student parents are indicated that they are not satisfied with the number of credit hours that they are enrolled in. Almost one-fifth (19.9\%) reported taking more credit hours than they would like, and $26.7 \%$ were taking fewer credit hours than they would like. We thought that we would see more students indicate they were taking fewer credits than they desired because of Emlen's (1990) 
research, which found that $44 \%$ of student parents at PSU were taking fewer credit hours than they would like.

The large difference in the number of student parents reporting taking fewer credit hours than they would like could be due to methodological issues with the question wording, rather than a drastic improvement in parents' desired enrollment status. For example, in Emlen's (1990) research he asked, "Are you taking fewer credit hours than you would like?" The primary researcher decided to use a more neutral question to avoid leading the respondents, "Which best describes your current enrollment status?" (See page 12) The change in the wording of the question makes comparisons over time difficult.

Information was not collected on the reasons why students were taking more credits than they would like. As the survey instrument was being developed, we focused on barriers than inhibited access to the students' desired enrollment status. In hindsight, it would have been very beneficial to gather information on the reasons why students might be taking more credit hours than they would like.

Student parent respondents who said they were taking fewer credit hours than they would like reported a variety of reasons. (See Table 10) 
Table 10: Self-Reported Reasons for Taking Fewer Credit Hours Than Desired (\%)

Difficulty paying for childcare costs 41.9

Want to spend more time with children

Full-time employee

Conflict w/work schedule

Financial Aid package was not enough

Not willing to take out extra student loans

Loss of job by self, spouse or partner

Other care-taking responsibilities

Personal problems

Trouble finding satisfactory quality childcare

Loss of Student Childcare Block Grant

4.7

$N=86$

As expected, $41.9 \%$ said they had difficulty paying for childcare costs. $10.5 \%$ said they were unable to find satisfactory quality childcare. Interestingly, $37.4 \%$ said that they are taking fewer credit hours than they would like so that they could spend more time with their children. Almost one-third (32.6\%) said they are full time employees, and $26.7 \%$ said their work schedules interfered with classes. Other reasons for taking fewer credit hours than they would like included that their financial aid package was not enough (25.6\%), they were not willing to take out extra student loans (19.7\%), they had other care-taking responsibilities $(12.8 \%)$, 
they experienced a loss of job by self, spouse, or partner (12.8\%), they had personal problems (11.6\%), and had lost the Student Childcare Block Grant $(4.7 \%)^{8}$.

\section{Hypotheses}

Hypothesis \#1: Female student parents will be more likely than male student parents to indicate that they are enrolled in fewer credit hours than they desire.

Female student parents were slightly more likely to indicate that they were taking fewer credit hours than they desired, but this was not statistically significant. (See Table 11)

Table 11: Student Parents' Subjective Enrollment Status, by Gender (\%)

\begin{tabular}{lcl}
\hline & $\underline{\text { Males }}$ & $\frac{\text { Females }}{(n=231)}$ \\
\hline More credit hours & 17.3 & 20.9 \\
Just as many credit hours & 59.3 & 51.1 \\
Fewer credit hours & 23.5 & 28.0 \\
\hline
\end{tabular}

$N=320$

$X^{2}=1.64(p=.440)$

About half (51.1\%) of females and $59.3 \%$ of males are taking just as many credit hours as they would like. However, $20.9 \%$ of females and $17.3 \%$ of males are taking more credit hours than they would like, and $28 \%$ of females and $23.5 \%$ of males reported taking fewer credit hours than they would like. Although we see

\footnotetext{
${ }^{8}$ The Student Childcare Block Grant was a small and under-funded program in Oregon that helped low-income student parents pay for childcare costs while they attended a post-secondary education program. The program was eliminated, due to budget cuts, in September of 2002.
} 
some evidence that females are more likely to be taking fewer credit hours than they would like, hypothesis \#1 is rejected.

Males and females did, however, report different reasons as to why they were taking fewer credit hours than they. would like. (See Table 11.1)

Table 11.1: Self-Reported Reasons for Taking Fewer Credit Hours Than Desired, by Gender (\%)

\begin{tabular}{|c|c|c|c|}
\hline & $\frac{\text { Males }}{(n=19)}$ & $\frac{\text { Females }}{(n=67)}$ & $F$ \\
\hline Full-time employee & 26.3 & 34.3 & .425 \\
\hline Conflict w/work schedule & 42.1 & 22.4 & $2.97^{*}$ \\
\hline $\begin{array}{l}\text { Loss of job by self, spouse } \\
\text { or partner }\end{array}$ & 5.3 & 14.9 & .271 \\
\hline $\begin{array}{l}\text { Financial Aid package was } \\
\text { not enough }\end{array}$ & 31.6 & 23.9 & .453 \\
\hline $\begin{array}{l}\text { Not willing to take out } \\
\text { extra student loans }\end{array}$ & 15.8 & 20.9 & .238 \\
\hline Personal problems & 5.3 & 13.4 & .950 \\
\hline $\begin{array}{l}\text { Other care-taking } \\
\text { responsibilities }\end{array}$ & 5.3 & 14.9 & 1.23 \\
\hline $\begin{array}{l}\text { Loss of Student Childcare } \\
\text { Block Grant }\end{array}$ & 0 & 6 & 1.18 \\
\hline $\begin{array}{l}\text { Want to spend more } \\
\text { time with children }\end{array}$ & 36.8 & 38.8 & .024 \\
\hline $\begin{array}{l}\text { Trouble finding satisfactory } \\
\text { quality childcare }\end{array}$ & 0 & 13.4 & $2.88^{*}$ \\
\hline $\begin{array}{l}\text { Difficulty paying for } \\
\text { childcare costs }\end{array}$ & 26.3 & 46.3 & 2.43 \\
\hline
\end{tabular}


Males most frequently reported that conflict with their work schedule was a reason for taking fewer credit hours than desired, while females overwhelmingly reported childcare-related reasons. We can see that childcare costs affect women's access to higher education more than men's; $46.3 \%$ of women and only $26.3 \%$ of men reported difficulty paying for childcare as a reason why they were enrolled in fewer credit hours than desired. No men were affected by the availability of quality childcare, and only one was affected by other care-taking responsibilities. Females' credit hours, however, are also affected by their employment status, but possibly in different ways. Just over one-third (34.3\%) of females and $26.3 \%$ of males cited that they were a full-time employee as a reason why they were taking fewer credits than they desired. This was curious because men were more likely to be working full-time than females in this sample. It may be that full-time is especially difficult for females because of their added child-rearing responsibilities.

Both males and females indicated frequently that they would like to spend more time with their children as a reason for taking fewer credit hours. It is clear that balancing work, school, and family responsibilities is affecting some student parents' ability to take as many credit hours as they would like. Even though males and females do not differ significantly when it comes to their desired enrollment status, we have evidence that they have different types of barriers.

Next, we examine student parents' subjective enrollment status by their gender and martial status. (See Table 12) 
Table 12: Student Parents' Subjective Enrollment Status, by Gender \& Marital Status (\%)

\begin{tabular}{|c|c|c|c|c|}
\hline & \multicolumn{2}{|c|}{ Males } & \multicolumn{2}{|c|}{ Females } \\
\hline & $\frac{\text { Married }}{(n=70)}$ & $\frac{\text { Single }}{(n=11)}$ & $\frac{\text { Married }}{(n=129)}$ & $\frac{\text { Single }}{(n=109)}$ \\
\hline More credits & 15.7 & 27.3 & 20.9 & 21.1 \\
\hline Just as many credits & 60.0 & 54.5 & 51.9 & 49.5 \\
\hline Fewer credits & 24.3 & 18.2 & 27.1 & 29.4 \\
\hline Chi-Square & \multicolumn{2}{|c|}{.666} & \multicolumn{2}{|c|}{1.33} \\
\hline
\end{tabular}

$N=319$

We can still see that females are slightly more likely than males to be taking fewer credit hours than they desire even when considering marital status, but we cannot be confident that this trend can be generalized to the larger population. Almost $30 \%$ of married and single females are taking fewer credit hours than they would like and about $20 \%$ are taking more. As expected, married males are the most likely group to say they are taking just as many credit hours as they desire.

Table 12.1 examines the reasons why student parents are taking fewer credits than they desire by both gender and marital status. 
Table 12.1: Self-Reported Reasons for Taking Fewer Credit Hours Than Desired, by Gender \& Marital Status ${ }^{1}$

\begin{tabular}{|c|c|c|c|c|}
\hline & $\frac{\text { Married }}{\frac{\text { Males }}{(n=17)}}$ & $\begin{array}{l}\frac{\text { Married }}{\text { Females }} \\
\frac{(n=35)}{(n=3.0}\end{array}$ & $\begin{array}{l}\frac{\text { Single }}{\text { Females }} \\
\frac{(n=32)}{(n=3}\end{array}$ & $F$ \\
\hline Full-time employee & 29.4 & 34.3 & 34.4 & .071 \\
\hline Conflict w/work schedule & 41.2 & 14.3 & 31.3 & $2.54^{*}$ \\
\hline $\begin{array}{l}\text { Loss of job by self, spouse } \\
\text { or partner }\end{array}$ & 5.9 & 11.4 & 18.8 & .868 \\
\hline $\begin{array}{l}\text { Financial Aid package was } \\
\text { not enough }\end{array}$ & 35.3 & 20 & 28.1 & .729 \\
\hline $\begin{array}{l}\text { Not willing to take out } \\
\text { extra student loans }\end{array}$ & 17.6 & 20 & 21.9 & .06 \\
\hline Personal problems & 5.9 & 8.6 & 18.8 & 1.185 \\
\hline $\begin{array}{l}\text { Other care-taking } \\
\text { responsibilities }\end{array}$ & 5.9 & 17.1 & 12.5 & .632 \\
\hline $\begin{array}{l}\text { Loss of Student Childcare } \\
\text { Block Grant }\end{array}$ & 0 & 0 & 12.5 & $3.58^{*}$ \\
\hline $\begin{array}{l}\text { Want to spend more } \\
\text { time with children }\end{array}$ & 29.4 & 42.9 & 34.4 & .503 \\
\hline $\begin{array}{l}\text { Trouble finding satisfactory } \\
\text { quality childcare }\end{array}$ & 0 & 17.1 & 9.4 & 1.82 \\
\hline $\begin{array}{l}\text { Difficulty paying for } \\
\text { childcare costs }\end{array}$ & 29.4 & 48.6 & 43.8 & .853 \\
\hline
\end{tabular}


Both married and single females are still overwhelmingly affected by childcare related barriers, but single females have the added burden of work barriers. Single females were, as expected, most affected by the loss of the Student Childcare Block Grant, which was a form of subsidized, reduced-cost childcare. Single females increased level of personal problems suggests that the added stress of being a single student parent is affecting their access to higher education.

How do student parents' objective and subjective enrollment status interact? Table 13 illustrates student parents' subjective and full-time/part-time objective enrollment status by their gender and marital status. Table 13.1 examines student parents' median enrolled credit hours, by their gender and marital status. Both undergraduates and graduates are grouped together in Table 13.1 because separate analysis did not significantly affect the median. Once again, single males are excluded due to small numbers. 
Table 13: Student Parents Subjective and Objective Enrollment Status, by Gender $\&$ Marital Status $(\%)^{1}$

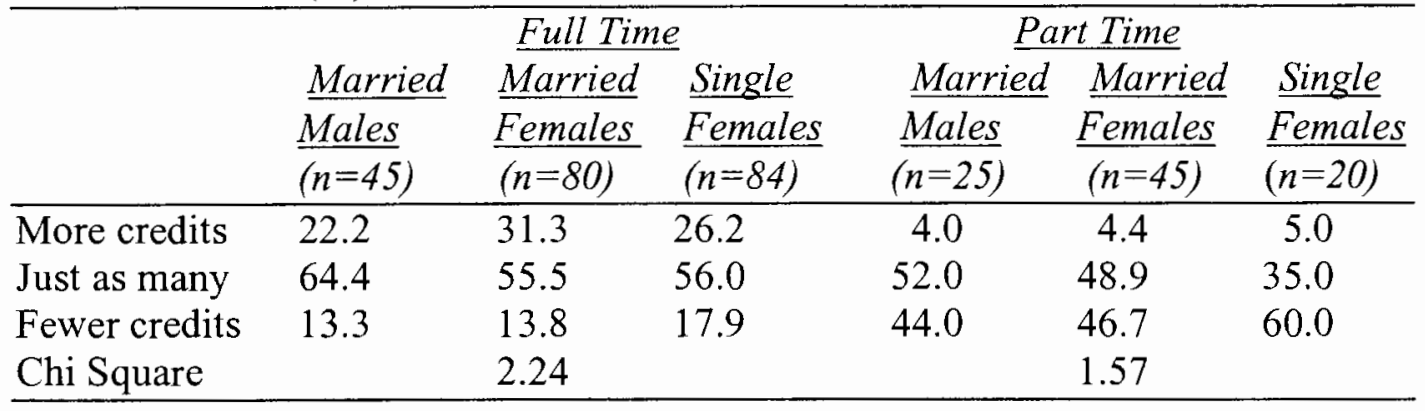

$N=299$

${ }^{1}$ There were only 11 single males in this sample, and so are excluded from this analysis.

Table 13.1: Median Number of Enrolled Credit Hours, by Subjective Enrollment Status, Gender, \& Marital Status ${ }^{1}$

\begin{tabular}{|c|c|c|c|c|c|c|}
\hline & \multicolumn{3}{|c|}{ Full Time } & \multicolumn{2}{|c|}{ Part Time } & \multirow[b]{2}{*}{$\frac{\frac{\text { Single }}{\text { Females }}}{(n=20)}$} \\
\hline & $\frac{\text { Married }}{\text { Males }}$ & $\frac{\frac{\text { Married }}{\text { Females }}}{(n=80)}$ & $\frac{\frac{\text { Single }}{\text { Females }}}{(n=84)}$ & $\frac{\text { Married }}{\text { Males }}$ & $\frac{\text { Married }}{\frac{\text { Females }}{(n=45)}}$ & \\
\hline Mor & 14.5 & 16.0 & 16.0 & 6.0 & 8.0 & 6.0 \\
\hline Just as many & 12.0 & 14.0 & 12.0 & 8.0 & 7.0 & 6.0 \\
\hline Fewer credits & 12.5 & 12.0 & 12.0 & 8.0 & 8.0 & 8.0 \\
\hline
\end{tabular}

$N=299$

${ }^{1}$ There were only 11 single males in this sample, and so are excluded from this analysis.

We can see that large numbers of both part-time and full-time students are dissatisfied with their number of enrolled credit hours. Although $77 \%$ of single females are already enrolled in school full-time, $17.9 \%$ still reported taking fewer credits than they would like. Their median credit load is 12 , while the median credit load of the $26.2 \%$ taking more credits than they would like is 16 . As expected, married males enrolled full-time are the most satisfied with their enrollment status. Almost one third of married females enrolled full-time say they are taking more credits than they would like, and their median is 16 credits. We can see that among those who say they are taking more credits than they desire, their 
credit load is quite high. Among part-time student parents, $60 \%$ of single females said they were taking fewer credits than they would like.

In summary, we found very little evidence to support hypothesis \#1.

Almost the same proportion of males and females report that they are taking fewer credit hours than they would like. However, women and men do tend to report different reasons as to why they are enrolled in fewer credits than they desire, with women much more likely to report childcare-related reasons. When we consider students' objective enrollment status, single females enrolled part-time or full-time are the most likely to report taking fewer credits than they would like. Although single females are more likely than married males and married females to be enrolled full-time, they are also more likely than other full-time student parents to want to take more credits than a minimum full-time load.

We have also found that many full-time students report taking more credit hours than they would like - these students tend to be those who are enrolling in many more hours than the full-time minimum credit load. It appears that students are using two different types of strategies in order to balance parenting and going to school. One strategy is to enroll in fewer credit hours than the student would prefer; the other is to "load up" on credit hours in order to get through school quickly. We will explore this possibility further in our analysis of Hypothesis $\# 2$. 
Hypothesis \#2: Student parents who are resource poor and do not have access to subsidized childcare will be more likely to report taking fewer credit hours than they would like compared to resource poor parents with access to subsidized childcare.

Resource poor student parents are defined as those who are low-income and who reported having monthly childcare costs. ${ }^{9}$

Resource Poor: $(n=106)$ : Non-Resource Poor $(n=226)$ :

1) At or below $200 \%$ of poverty threshold and

2) Reported having childcare costs
1) Above $200 \%$ of poverty threshold

2) Reported having no childcare costs

Who Are Resource Poor Student Parents?

Almost one-third $(31.9 \%)$ of student parents in the sample met the criteria for being defined as resource poor. Resource poor student parents differ significantly from those who are not resource poor. (See Table 14)

\footnotetext{
${ }^{9}$ See Methodology Chapter for a complete operational definition of "low-income" and "resource poor."
} 
Table 14: Characteristics of Resource Poor and Non-Resource Poor Student Parents Resource Poor Non-Resource

$\underline{(n=106)} \quad \frac{\text { Poor }}{(n=226)} X^{2}$

\begin{tabular}{llrr} 
& & $(n=226)$ & \\
\hline \% Single female & 55.7 & 23.5 & $40.25^{* *}$ \\
$\%$ Married female & 29.2 & 46.1 & \\
$\%$ Married male & 9.4 & 28.1 & \\
$\%$ Single male & 5.7 & 2.3 &
\end{tabular}

$\%$ Single, divorced, separated

61.3

25.8

$38.34 * *$

Mean hours worked per week

12.91

19.11

$9.93^{1 * *}$

$\%$ Enrolled full-time

77.8

66.8

$3.87^{*}$

Mean monthly cost of

324.15

143.35

$33.67^{1} *$

childcare (\$)

$\%$ Who have someone available

51.5

75.1

$16.99^{* *}$

to provide unpaid childcare

$\%$ Who have a young child

69.8

58.7

$3.74 *$

(ages 0-5)

$\%$ Missing 3 or more classes

28.5

16.8

$23.94 * *$

due to childcare issues

$\%$ Who are using any form of

43.1

7.9

$51.47^{* *}$ subsidized childcare

$\begin{array}{ll}N=332 & * * p<.01 \\ * p<.05 & { }^{1} F \text { statistic. }\end{array}$

Of resource poor student parents, $84.8 \%$ are female and $15.2 \%$ are male $\left(X^{2}=8.70, p<.01\right)$. Single females compose $55.7 \%$, married females $29.2 \%$, married males $9.4 \%$, and single males $5.7 \%$ of resource poor student parents. As anticipated, females, especially single females, are much more likely to be resource poor. Resource poor student parents reported working fewer hours per week, 
which may partially explain their low-income status. However, resource poor student parents are more likely to be enrolled in school full-time. This confirms previous research findings (Emlen, 1990) of the inverse relationship between hours worked and enrolled credit hours.

The mean monthly childcare expenditure for resource poor students is $\$ 324.15$, compared to $\$ 143.35$ among those who are not resource poor ${ }^{10}$. However, resource poor student parents are much more likely to be utilizing any type of subsidized childcare ( $43.1 \%$ versus $7.9 \%$ respectively). Resource poor student parents are also much less likely to have someone available to provide childcare free of charge. Furthermore, they are more likely to have young children who have not yet started kindergarten, and thus have higher childcare costs $(69.8 \%$ versus $58.7 \%$ respectively). The mean age of the youngest child for resource poor student parents is 4.25 years and for non-resource poor parents is 6 years $(p<.01)$. Resource poor student parents are much less likely to be using forms of unpaid childcare, such as self-care ( $1 \%$ versus $19.3 \%$ respectively, $p<.01)$. This further supports the finding that student parents with young children not yet in school are more likely to have childcare costs, and that non-resource poor student parents tend to have older children who do not require paid childcare. As expected, resource poor student parents are also much more likely to miss classes due to childcare issues. All of these differences were statistically significant.

\footnotetext{
${ }^{10}$ By definition, student parents who have no monthly childcare costs are not resource poor. However, student parents who are not resource poor also include those with childcare costs, but who are above $200 \%$ of the poverty threshold.
} 
Who Are Student Parents Accessing Subsidized Childcare?

There are also many significant differences between students who are accessing subsidized childcare and those who are not. (See Table 15) It is clear that students who are lacking or missing other critical childcare resources utilize childcare subsidies.

Table 15: The Importance of Subsidized Childcare

\begin{tabular}{|c|c|c|c|}
\hline & $\frac{\text { No Childcare Subsidy }}{(n=272)}$ & $\begin{array}{l}\text { Has Childcare } \\
\text { Subsidy }(n=56)\end{array}$ & $X^{2}$ \\
\hline$\%$ Female & 68.1 & 98.2 & $23.30^{*}$ \\
\hline$\%$ Single & 29.4 & 64.3 & $24.98^{*}$ \\
\hline $\begin{array}{l}\% \text { Who have someone to } \\
\text { provide unpaid childcare }\end{array}$ & 69.8 & 52.7 & $8.38^{*}$ \\
\hline $\begin{array}{l}\% \text { Whose primary childcare } \\
\text { arrangement is unpaid }\end{array}$ & 38.7 & 12.7 & $149.0^{*}$ \\
\hline$\%$ Low-income ${ }^{1}$ & 50.8 & 85.2 & $20.96^{*}$ \\
\hline$\%$ Enrolled full-time & 69.0 & 80.4 & $2.70 * *$ \\
\hline $\begin{array}{l}* * p=.067 \\
\text { 'For definitior }\end{array}$ & 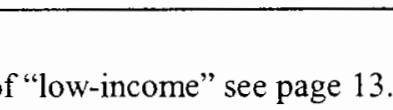 & & \\
\hline
\end{tabular}

All but one student with a childcare subsidy was female. Many (64.3\%) students with childcare subsidies have no spouse or partner, compared to $29.4 \%$ of those without subsidized childcare. Among those with a subsidy, $52.7 \%$ have someone who provides childcare free of charge. Among those without a subsidy, $69.8 \%$ have this important resource available. While only $12.7 \%$ of students with childcare subsidies have their primary childcare arrangement free of charge, $38.7 \%$ 
of those without do so. The vast majority ( $85.2 \%)$ of students with a childcare subsidy are low-income, compared to $50.8 \%$ of those without.

As expected, student parents with access to subsidized childcare are more likely to be enrolled in school full-time than those without. $80.4 \%$ of those with subsidized childcare and $69 \%$ of those without are enrolled full-time. Students who are accessing subsidized childcare are the group who appears to need it the most; we speculate that it is the presence of subsidized childcare that facilitates this group of students' access to higher education.

Answering Hypothesis \#2

Now that we have an idea of who resource poor students are and also who is accessing subsidized childcare, we can answer hypothesis \#2. Resource-poor student parents with access to subsidized childcare were actually more likely to indicate that they were taking fewer credit hours than they would like, but this was not statistically significant. However, resource poor student parents without access to subsidized childcare were almost two times more likely to say they were taking more credit hours than they would like. (See Table 16)

Table 16: Subjective Enrollment Status of Resource Poor Student Parents, by Access to Subsidized Childcare (\%)

\begin{tabular}{lcc}
\hline & $\frac{\text { Has Childcare }}{\text { Subsidy }}$ & $\frac{\text { Has No Childcare }}{\text { Subsidy }}$ \\
& $\frac{(n=43)}{(n=58)}$ & 31.1 \\
\hline More credit hours than would like & 16.7 & 45.9 \\
Just as many as would like & 47.6 & 23.0 \\
Fewer credit hours than would like & 35.7 &
\end{tabular}

$N=101$

$X^{2}=3.58(p=.167)$ 
When we look at only resource poor student parents, we find that $23 \%$ $(n=14)$ of resource poor student parents without a childcare subsidy reported taking fewer credit hours than they would like; $35.7 \%(n=15)$ of resource poor student parents with a childcare subsidy reported the same. It is interesting that among resource poor student parents, $31.1 \%$ of those without a childcare subsidy reported taking more credit hours than they would like, while only $16.7 \%$ of those with a childcare subsidy reported the same. This suggests that student parents without childcare subsidies are more likely to feel overloaded on credit hours.

When we look more closely and consider only resource poor student parents who are not satisfied with the number of credit hours they are enrolled in $(n=55)$, we find that $68.2 \%$ of those with a childcare subsidy are taking fewer credit hours than they would like, while $42.4 \%$ of those without a subsidy reported the same. $31.8 \%$ of those with a subsidy reported taking more credit hours and $57.6 \%$ of those without are taking more credit hours than they desire.

Table 17: Subjective Enrollment Status of Resource Poor Student Parents Who Are Taking Fewer or More Credit Hours Than They Desire, by Access to Subsidized Childcare (\%)*

\begin{tabular}{lll}
\hline & $\frac{\text { Has Childcare }}{\text { Subsidy }}$ & $\frac{\text { Has No Childcare }}{\text { Subsidy }}$ \\
& $\frac{(n=22)}{(n=31)}$ & 57.6 \\
\hline More credits than would like & 31.8 & 42.4 \\
\hline
\end{tabular}

$N=55$

${ }^{*} X^{2}=3.51(p=.054)$

If we consider the objective enrollment status of resource poor student parents, we find that a large majority $(77.8 \%)$ are already enrolled full-time. 
However, resource poor student parents with access to subsidized childcare were more likely to be enrolled full-time. When we compare resource poor student parents who have access to subsidized childcare to those who do not, we find that $82.1 \%(n=32)$ of resource poor students with access to subsidized childcare are enrolled full-time compared to $74.6 \%(n=44)$ of resource poor students without access to subsidized childcare. However, this failed to achieve statistical significance $\left(X^{2}=.754, p=.270\right)$.

Next, we will consider how students' objective and subjective enrollment status work together. Table 18 looks at students' full-time/part-time status and Table 18.1 displays their median enrolled credit load to again explore the "rushing" phenomenon. Both graduate and undergraduates are grouped together because separate analysis did not significantly affect the median. 
Table 18: Subjective Enrollment Status of Resource Poor Student Parents, by Access to Subsidized Childcare \& Enrollment Status (\%)

\begin{tabular}{lllccc}
\hline & \multicolumn{2}{c}{ Full-Time } & \multicolumn{2}{c}{ Part-Time } \\
& \multicolumn{1}{c}{ Subsidy } & $\frac{\text { No Subsidy }}{(n=33)}$ & $(n=41)$ & $\frac{\text { Subsidy }}{(n=7)}$ & $\frac{\text { No Subsidy }}{(n=14)}$ \\
\hline More credits & 21.9 & 41.9 & 0 & 6.7 \\
Just as many credits & 53.1 & 48.8 & 28.6 & 46.7 \\
Fewer credits & 25.0 & 9.3 & 71.4 & 46.7 \\
Chi-Square & & $5.09^{*}$ & \multicolumn{2}{c}{1.38} \\
\hline
\end{tabular}

$N=97$

${ }^{*} p<10$

Table 18.1: Resource Poor Student Parents' Median Enrolled Credit Hours, by PT/FT Status \& Access to Subsidized Childcare

\begin{tabular}{lcccc}
\hline & \multicolumn{2}{c}{ Full-Time } & \multicolumn{2}{c}{ Part-Time } \\
& $\frac{\text { Subsidy }}{(n=33)}$ & $\frac{\text { No Subsidy }}{(n=41)}$ & $\frac{\text { Subsidy }}{(n=7)}$ & $\frac{\text { No Subsidy }}{(n=14)}$ \\
\hline More credits & 16.0 & 16.0 & N/A & 6.0 \\
Just as many credits & 12.0 & 12.0 & 7.0 & 7.0 \\
Fewer credits & 12.5 & 11.5 & 8.0 & 8.0 \\
\hline
\end{tabular}

$N=97$

When considering how students' objective and subjective enrollment status work together, we find that students enrolled full-time with no childcare subsidy are the most likely group to indicate that they are taking more credits than they would like. However, it is the part-time students with a childcare subsidy who are the most likely to be taking fewer credits than they would like.

The majority of part-time resource poor student parents are taking fewer credits than they would like, but having access to subsidized childcare seems to make little difference. Small numbers in this analysis make estimates unreliable, but this suggests that having access to subsidized childcare was not enough to bring 
resource poor student parents enrolled part-time up to their desired enrollment status.

Why would students who are already enrolled full-time still indicate that they are taking fewer credit hours than they would like? A possible explanation is that at the time of this study the tuition structure was such that students paid the same full-time price for tuition if they were taking 12 credits all the way up to 18 credits. This, along with the surprisingly high numbers of students who indicated that they were enrolled in more credit hours than they would like while enrolled in heavy credit loads (16 or more), suggests that student parents are taking advantage of the tuition pricing structure and trying to rush through their education. Students who are taking fewer credits than they would like may actually wish they were overloading on credits in order to decrease costs and graduate faster.

Access to subsidized childcare does not seem to be enough to even boost full-time resource poor student parents' to their desired enrollment status. This suggests that students with the fewest resources are the most likely group to want to use the rushing strategy to get through school.

In summary, hypothesis \#2, as it was originally stated, was not supported. It seems that the interplay between students' subjective and objective enrollment status tells a much more complex story of the coping strategies student parents utilize. Even though resource poor student parents with access to subsidized childcare were actually more likely to be already enrolled full-time, they were also more likely to report taking fewer credit hours than they would like. However, we 
did find that having access to subsidized childcare might decrease the tendency for resource poor students to feel overloaded on credit hours. We have suggested that the "rushing" through higher education phenomenon we have observed may be a product of the tuition pricing structure that allows students to pay a flat rate for fulltime enrollment. Students who enroll in many credits per term are mostly likely attempting to decrease the costs associated with higher education by going through school at an accelerated pace, even though they may not want to.

In answering hypothesis \#2, we have also discovered many significant differences between students who have access to subsidized childcare and those who do not. Subsidized childcare is a critical resource for student parents who are lacking and/or missing other critical childcare resources. Without subsidized childcare, it is doubtful that this group of student parents would be able to continue accessing higher education.

Hypothesis \#3: Female student parents who are enrolled full-time will be less satisfied with their primary childcare arrangement than female student parents who are enrolled part-time.

As Table 19 indicates, female student parents who are enrolled full-time tend to be less satisfied with their primary childcare arrangement than females enrolled part-time, but this failed to achieve statistical significance. 
Table 19: Females' Level of Satisfaction with Primary Childcare Arrangement, by Full-Time \& Part-Time Status (\%)

\begin{tabular}{lcc}
\hline & $\frac{\text { Full-Time }}{(n=156)}$ & $\frac{\text { Part-Time }}{(n=56)}$ \\
\hline Very satisfied & 55.1 & 69.6 \\
Somewhat satisfied & 35.9 & 23.2 \\
Somewhat or very concerned & 9.0 & 7.2 \\
\hline
\end{tabular}

$N=212$

$X^{2}=3.67(p=.159)$

A cross-tabulation indicated that $69.6 \%$ of female students enrolled parttime reported being "very satisfied" with their primary childcare arrangement, compared to $55.1 \%$ of full-time females. $23.2 \%$ of part-time and $35.9 \%$ of fulltime females said they were "somewhat satisfied." $7.2 \%$ of part-time and $9 \%$ of full-time females felt "somewhat" or "very concerned" about their primary childcare arrangement.

To examine this relationship further, we consider the marital status of these women. We find that married part-time females are the most satisfied with their primary childcare arrangement, but single part-time females are also more satisfied than both married and single full-time students. (See Table 19.1)

Table 19.1: Females' Level of Satisfaction with Primary Childcare Arrangement, by Enrollment Status \& Marital Status (\%)

\begin{tabular}{lllll}
\hline & \multicolumn{2}{c}{ Full-Time } & \multicolumn{2}{c}{ Part-Time } \\
& Single & $\frac{\text { Married }}{(n=78)}$ & $\frac{\text { Single }}{(n=18)}$ & $\frac{\text { Married }}{(n=38)}$ \\
\hline Very satisfied & 55.1 & 54.5 & 66.7 & 71.1 \\
Somewhat satisfied & 34.6 & 37.7 & 22.2 & 23.7 \\
Concerned & 10.3 & 7.8 & 11.1 & 5.3 \\
Chi-Square & & .362 & & \multicolumn{2}{c}{.630} & \\
\hline
\end{tabular}

$N=211$ 
Among single female students enrolled full-time, $55.1 \%$ are very satisfied, $34.6 \%$ somewhat satisfied, and $10.3 \%$ concerned. Among married/partnered female student parents enrolled full-time, $54.5 \%$ are very satisfied, $37.7 \%$ somewhat satisfied, and $7.8 \%$ concerned. Among single female students enrolled part-time, $66.7 \%$ are very satisfied, $22.2 \%$ somewhat satisfied, and $11.1 \%$ concerned. Among married/partnered female student parents enrolled part time, $71.1 \%$ are very satisfied, $23.7 \%$ somewhat satisfied, and $5.3 \%$ concerned.

Although these findings failed to achieve statistical significance, hypothesis \#3 is conditionally accepted. We have observed a large percentage point difference in satisfaction between female student parents enrolled part-time and full-time. Furthermore, this relationship continues to exist when we consider the marital status of these women. We have evidence that part-time females in this sample are more satisfied with their primary childcare arrangement than females enrolled fulltime. This suggests that females enrolled full-time are making a trade-off between their level of involvement in higher education and their satisfaction with childcare. Next, we explore whether the group most vulnerable to making trade-offs are affected by the availability of subsidized childcare.

Hypothesis \#4: Full-time resource-poor female student parents who have access to subsidized childcare will be more satisfied with their primary childcare arrangement than full-time resource-poor female student parents who do not have access to subsidized childcare. 
There was very little difference between resource poor females' level of satisfaction with their primary childcare arrangement by access to subsidized childcare. However, we can see again the importance of subsidized childcare for resource poor full-time females; more than half have access to subsidized childcare. (See Table 20)

Table 20: Full-Time Resource-Poor Females Level of Satisfaction with Primary Childcare Arrangement, by Access to Subsidized Childcare (\%)

\begin{tabular}{lcc}
\hline & Subsidized Childcare & No Subsidized Childcare \\
\cline { 2 - 3 }$(n=32)$ & $(n=31)$ \\
\hline Very satisfied & 56.3 & 54.8 \\
Somewhat satisfied & 34.4 & 38.7 \\
Somewhat or very concerned & 9.4 & 6.5 \\
\hline$N=63$ & & \\
$X^{2}=.256,(p=.880)$ &
\end{tabular}

Among resource poor female student parents who are enrolled full-time and do not have a childcare subsidy, $54.8 \%$ are very satisfied, $38.7 \%$ somewhat satisfied, and $6.5 \%$ reported being somewhat or very concerned about their primary childcare arrangement. Among resource poor female student parents enrolled fulltime and have a childcare subsidy, $56.3 \%$ reported being very satisfied, $34.4 \%$ somewhat satisfied, and $9.4 \%$ concerned.

In trying to determine why there was no relationship, we decided to consider the age of the youngest child because younger children require much more childcare and thus greater childcare costs. Resource poor students with a young child are the most likely group whom subsidized childcare is likely to be a critical resource. When we look at resource poor females' satisfaction by subsidy and the age of their youngest child, we find a partial explanation for why we have observed 
very little difference. Full-time resource poor females with young children who have access to subsidized childcare do tend to be slightly more satisfied with their childcare than those without subsidized childcare, but small numbers make these estimates unreliable. (See Table 20.1) The small number of full-time resource poor female students with school-age children makes these estimates even less reliable.

20.1: Full-Time Resource-Poor Females' Level of Satisfaction with Primary Childcare Arrangement, by Access to Subsidized Childcare \& Age of Child (\%)

\begin{tabular}{lccccc}
\hline & \multicolumn{2}{c}{ Young Child } & & \multicolumn{2}{c}{ School-Age Child } \\
& $\frac{\text { Subsidy }}{(n=27)}$ & $\frac{\text { No Subsidy }}{(n=16)}$ & & $\frac{\text { Subsidy }}{(n=5)}$ & $\frac{\text { No Subsidy }}{(n=15)}$ \\
\hline Very satisfied & 63.0 & 56.3 & 20.0 & 53.3 \\
Somewhat satisfied & 33.3 & 37.5 & 40.0 & 40.0 \\
Concerned & 3.7 & 6.3 & 40.0 & 6.7 \\
Chi-Square & & .265 & & & 3.70 \\
\hline
\end{tabular}
$N=63$

Among full-time resource poor female students with young children, we see that those with access to subsidized childcare are slightly more satisfied with their primary childcare arrangement. However, the small numbers make this analysis difficult. At least for now, hypothesis \#4 is rejected.

To further explore the reasons why we have observed very little difference, we decided to look at the type and cost of the childcare that full-time resource poor females with young children $(n=43)$ were utilizing for their primary childcare arrangement. These are the students utilizing the most amount of paid childcare, have the fewest resources, but are still enrolled full-time. For those without a subsidy, $43.8 \%$ are using an in-home paid relative or non-relative, and the median monthly childcare cost is $\$ 370.00$. For those with a subsidy, $59.3 \%$ are using a 
subsidized childcare center, and the median monthly childcare cost is $\$ 340.00$. We find that full-time resource poor females who do not have access to subsidized childcare have managed to find inexpensive (almost the same price as those with subsidized childcare) but satisfactory quality childcare, and this probably explains how they are still able be enrolled in school full-time.

\section{Different Strategies for Different Students}

What emerged from this data and the exploration of these hypotheses is that student parents are a very diverse group in terms of the strategies they use in trying to balance work, childcare, and their involvement in higher education. Student parents at PSU are masters at "making it work." However, some student parents are making trade-offs; some work more hours per week and have higher household incomes, yet this constrains their ability to enroll full-time. Other students work fewer hours per week or not at all, have less household income, but are more likely to enroll full-time. Some students have resources that allow them to go to school with no childcare costs. Others juggle a variety of paid and unpaid childcare arrangements in order to decrease their childcare expenditures. Some students have found ways to access subsidized childcare and also decrease their childcare costs. These are just some of the strategies that student parents utilize that have emerged from this data. What follows is a general description of the different types of strategies and the types of student parents most likely to use them. 
Strategy \#1: Avoid the cost of childcare altogether

Groups most likely to use this strategy: Married males, some married females, and a small number of single females.

A large percentage (42.8\%) of student parents reported having no childcare costs. This is certainly an effective strategy, and probably the most optimal one for dealing with childcare issues. The majority of men in our sample had no childcare costs because their spouse or partner provided their childcare. This was due to men's increased likelihood of being married while they were enrolled in higher education, but also because of the gendered division of labor. For these men, the trade-off was between their enrollment and the number of hours they worked per week. While working more hours per week provides a higher household income for men, it also decreases their likelihood of being enrolled full-time in school. However, it probably allows their wife to stay home and provide unpaid childcare.

Some married women also had no childcare costs. These women were utilizing their spouse, partner, friend, and/or relative to provide unpaid childcare while they accessed higher education. However, their care-taking responsibilities impeded their access to higher education, and they were just as likely as married men to be enrolled in school part-time.

A small percentage of single females also reported having no childcare costs. These were mostly the women who waited to enroll in higher education until their child was old enough to not require childcare. Some single females with younger children had a relative or friend who provided all of their unpaid childcare, 
and a few were accessing free childcare programs. This allowed the large majority of single females to enroll full-time.

\section{Strategy \#2: Arrange for both paid and unpaid care}

Groups most likely to use this strategy: All types of students.

Many student parents $(28.6 \%)$ have a spouse, partner, relative, or friend who is able to provide some, but not all of their childcare free of charge. This was an important resource that helped minimize the cost of childcare. All types of student parents used this strategy, but some certainly had more of this resource than others. When student parents were forced to pay for childcare, many used relatively inexpensive daycare such as a family daycare home, and some accessed subsidized childcare. Married females who arrange for paid and unpaid care had more monetary resources available to them, but some still utilized subsidized childcare centers to decrease their childcare costs.

\section{Strategy \#3: Arrange for paid childcare}

Groups most likely to use this strategy: Many single females, some married females and males.

Many student parents $(26.8 \%)$ were not fortunate enough to have their childcare expenditures offset by having access to unpaid childcare. The married males and females of this group had higher household incomes that probably allowed them to more easily afford full-cost childcare. However, single females were the most likely group to be using all paid childcare, but were also the most likely to utilize subsidized childcare. Reduced-cost childcare is a crucial resource 
for students who are low-income and lack unpaid childcare. Single females were the most likely group to be enrolled in school full-time, but had the highest amounts of student loan debt. I speculate that single females, who have the fewest resources available to them, are the most likely group to want to use the "rushing" strategy to get through school. 


\section{Conclusion}

Three-quarters of student parents at Portland State University are women. Female student parents who are accessing higher education differ from male student parents significantly. Female student parents are much less likely to be married/partnered, are more likely to be low-income, are much more likely to be using forms of paid childcare, generally work fewer paid hours than males, but are incurring much larger amounts of student loan debt. Some, but not all, of the disadvantages women face are due to their marital status, in that they are missing a partner as a crucial resource to provide household income, support, and unpaid childcare. However, married females are still much less likely than married males to have access to unpaid childcare, and they were actually slightly more likely than single females to indicate that the cost of childcare was a barrier to their access to higher education. The experience of being a student parent is highly gendered, and we can see the effects of the unequal distribution of childcare labor. Childcare is a substantial barrier to higher education for women.

Student parents at PSU are a highly adaptable and determined group. Despite the challenges of balancing family, work, and school responsibilities, they are performing very well academically, and are actually more likely to be enrolled in school full-time than the general PSU student body.

Student parents are utilizing a variety of childcare arrangements and resources in order to meet their childcare needs while they access higher education. However, more childcare resources are desperately needed at Portland State 
University. Most student parents have young children who are not yet in school and require large amounts of childcare. Only a very small proportion of student parents have access to forms of subsidized childcare. The long waiting lists at the oncampus subsidized childcare centers provide strong evidence of student parents' preference for high-quality, low-cost childcare. Yet, despite the limited amount of subsidized childcare, student parents are finding ways to adapt. They face many barriers, but it does not seem to inhibit their enrollment in higher education. But what are the costs?

Even though student parents are more likely to be enrolled full-time than other PSU students, almost half are not enrolled in their desired number of credit hours. Some students are enrolled in fewer credits while others are enrolled in more credits than they would like. I have suggested that either taking more or fewer credit hours is a product of the barriers that student parents face. The tuition pricing structure that allows a flat rate for full-time enrollment is one explanation of why students are overloading on credit hours. Students are attempting to rush through their education in order to reduce the costs associated with being a student.

The paradox of this research is that student parents who have access to subsidized childcare are more likely to be taking fewer credit hours than they would like, even though they are objectively more likely to be enrolled full-time. It appears that students with the fewest resources available to them, which are the student parents accessing subsidized childcare, are the most likely to prefer using the rushing strategy. 
Again, when we look at who is accessing subsidized childcare, we find that it is the student parents with the fewest resources available to them.

Overwhelmingly, they are low-income single females. And, even though $81 \%$ of single females are enrolled full-time, access to subsidized childcare does not seem to be enough to allow them to be enrolled at their desired credit level because they prefer to overload on credit hours. With the end of the flat rate tuition for full-time enrollment coming within the next year, will students still enroll in more credits than they would like as a strategy to get through school?

Are female student parents pressured into sacrificing their satisfaction with their childcare arrangements in order to gain full access to higher education? We have evidence that female student parents enrolled full-time are less satisfied with their childcare than those enrolled part-time regardless of marital status. Full-time female student parents may be making costly trade-offs in order to pursue their education.

Subsidized childcare is a critical resource for student parents who are lowincome and do not have access to forms of unpaid childcare. We have observed that among resource poor females with young children who are enrolled full-time despite these barriers, the vast majority had access to subsidized childcare. It is likely that without subsidized childcare they would drop down to part-time enrollment, consider less expensive and/or less satisfactory childcare arrangements, or simply not be able to enroll in school at all. 
One of the major drawbacks of this research was the sample size, which constrained, if not prohibited, most of the multivariate analysis on subpopulations. Student parents are a very diverse population in that there are a multitude of strategies for dealing with childcare arrangements and costs that allow access, however varied, to higher education. Student parents are masters at adapting and seem very determined to pursue their education despite barriers they may face. The experience of being a student parent varies significantly by gender, marital status, class, and the age of the youngest child. A sample size large enough to allow multivariate analysis on each subpopulation is greatly needed.

Although we have speculated as to why students are enrolled in more credit hours than they would like, it would be informative to have collected data on this phenomenon. Also, asking student parents to directly voice their opinion on the importance of subsidized childcare would be valuable. An in-depth qualitative analysis would be extremely beneficial to capture the complexities and extent to which student parents are daily grappling with childcare and access to higher education.

The sample of student parents was not, unfortunately, representative of all student parents at Portland State University. Even though all students are eligible for Federal Student Loans, student parents who do not apply for Federal Financial Aid do not appear in this study. These students may be accessing higher education through their own earned income, scholarships, or employer-sponsored programs. 
Students who do not apply for Financial Aid have more resources available to them, but this research was primarily interested in students who are resource poor.

It is important to remember that this research focused on student parents already accessing higher education. Student parents who have achieved access have at least some resources available to them. Parents who would like to access higher education, but are faced with barriers that do not even allow them to set foot in the door, do not appear in this study.

Has the population of student parents who are able to access higher education changed? In 1990 , Emlen found that $65 \%$ of student parents were single females, compared to $45 \%$ in this research. This could be indicative of the changes since welfare reform, which have made it more difficult for low-income single females to access higher education.

Subsidized childcare is a great facilitator for parents who are missing and/or lacking other critical childcare resources. Although researchers are studying the effects of subsidized childcare on working families, it is important to also keep in mind families who are struggling to gain access to higher education. Many of these families are striving to achieve self-sufficiency and break away from the cycle of poverty. Given the strong correlation between higher education and socioeconomic status, subsidized childcare is a wise investment in these families' future. 


\section{REFERENCES}

Abramovitz, Mimi. (1988) Regulating the Lives of Women. Massachusetts: South End Press.

Berger, Mark C. and Black, Dan A. (1992). "Child Care Subsidies, Quality of Care, and the Labor Supply of Low-Income Single Mothers." The Review of Economics and Statistics. 74(4):635-642.

Bivin, David and Rooney, Patrick Michael (1999). "Forecasting Credit Hours." Research in Higher Education, 40(5):613-632.

Blau, Francine D. (1998). "Trends in the Well-Being of American Women, 1970-1995." Journal of American Economic Literature, 36:112-65.

Coalition for Independence Through Education (CFITE). (2002, Feb.) "Access and Barriers to Post-Secondary Education Under Michigan's Welfare to Work Policies."

Corcoran, M. and Loeb, S. (1999, Spring) "Will wages grow with experience for welfare mothers?" Focus, 20 (2):20-21.

Dillman, Don; Christenson, James A.; Carpenter, Edwin H.; Brooks, Ralph M. (1974). "Increasing Mail Questionnaire Response: A Four State Comparison." American Sociological Review, 39, (5):744-758.

Emlen, Arthur. (August 1990). "Student Parents at an Urban University: A survey of how financial aid applicants at Portland State University balance schoolwork, jobs, career planning, childcare and family life." Portland State University, Regional Research Institute for Human Services.

Emlen, Arthur C. and Emlen, Matthew D. (December 1991). "Student Parents at an Urban University: Balancing Schoolwork, Jobs, Child Care, Family, and Financial Aid." Portland State University, Regional Research Institute for Human Services.

Emlen, Arthur C. and Emlen, Matthew D. (March 1991). "Aiding Student Parents at Portland State University." Portland State University, Regional Research Institute for Human Services. 
Fadale, L.M. \& Winter, G.M. (1991). "Campus-based child care and the academic success of student-parents." Community College Journal of Research and Practice, 15 (2):15-123.

Gettell, M. Schehl, M. and Fareri, C. (1990). "From welfare to independence: The college option: A report to the Ford Foundation." New York: Howard Samuels State Management and Policy Center.

Gonchar, Nancy. (1995). "College-student mothers and onsite child care: luxury or necessity?" Social Work in Education. 17(4):226-234.

Maume, David J. (1991). "Childcare Expenditures and Women's Employment Turnover." Social Forces. 70(2):495-508.

Mishel, Lawrence; Bernstein, Jared; Boushey, Heather. 2003. The State of Working America: 2002-2003. Ithica, NY: Cornell University Press.

Okun, Morris A.; Benin, Mary; Brandt-Williams, Ann. "Staying in College: Moderators of the Relation between Intention and Institutional Departure." Journal of Higher Education, 67(5):577-596.

Pavetti, L. (1999, Spring) "How much more can welfare mothers work?" Focus, 20(2):16-19.

Perkins, George; Pitter, Gita Wijesinghe; Howat, Claudia; Whitfield, Duane. (1999). "Relationship of Financial Aid, Work and College Performance." Paper Presented at the Annual Forum of the Association for Institutional Research (39th, Seattle, WA, May 30-June 3, 1999).

Sapiro, V. (1999). Women in American Society: An Introduction to Women's Studies, 4th ed. London: Mayfield.

Smith, Kristin. Who's Minding the Kids? Child Care Arrangements: Spring 1997. Current Population Reports, P70-86. U.S. Census Bureau, Washington, DC, 2002.

Stratton, Leslie S.; O' Toole, Dennis M.; Wetzel, James N. (2001). "Factors Affecting Part-Time Enrollment within the First Year." Paper Presented at the Annual Meeting of the Association for Institutional Research (41st, Long Beach, CA, June 3-6, 2001). 


\section{Appendix A: Cover Letter}

Greetings!

My name is Dawn Creach and I am a graduate student in the Sociology Department at Portland State University. I am beginning a study about student parents at PSU. As a single mother and student myself, I am well aware of the challenges we face while balancing family, work, and school responsibilities. I would like to invite you to participate in this exciting research so that we can better understand the needs and experiences of student parents such as yourself.

If you decide to participate, you will complete the enclosed survey and return it in the postage-paid envelope. The survey contains questions about your current childcare arrangements, your experiences as a student parent, and information about you. It should take approximately 15 minutes to complete.

The results of this study will be presented to the PSU President's Commission on the Status of Women, Student Parent Services, and other school administrators. Although you may not receive any direct benefit from taking part in this study, the information that is collected will inform policy making and resource allocation at PSU.

This survey has been sent to you through the office of Student Parent Services. Your name and address are completely anonymous to me, the primary researcher. The identification number located on your survey and return envelope will only be used to send a replacement survey to those who have not responded. After you return your survey, you will be assigned a case number so that no information can be traced back to you.

Your participation in this study is voluntary. If you decide not to participate, your relationship with PSU and Student Parent Services will not change in any way. Please keep a copy of this letter for your records. If you have concerns or problems about your participation in this study or your rights as a research subject, please contact the Human Subjects Research Review Committee, Office of Research and Sponsored Projects, 111 Cramer Hall, Portland State University, (503) 725-3423. If you have any questions about the study itself, you can contact me at Portland State University, Department of Sociology, Cramer Hall 217X, (503) 725-9025.

Thank you, in advance, for taking the time to fill out and return this short survey. Please return your survey by May 7, 2003. Your participation is critical for the success of this study.

Sincerely,

E. Dawn Creach

Portland State University

Department of Sociology 


\section{Appendix B: Survey Instrument}

We are trying to get a picture of how your child is cared for while you are in classes, working, or studying. If you have more than one child, please tell us about your youngest child only.

If your youngest child is in Kindergarten through High School, please start on the next page Q.\#5 If your youngest child is age $0-5$, and has not started kindergarten yet, please start on this page.Q\#1. Please provide information for EACH different type of care that you use for your youngest child. For example, if your child attends preschool 2 days per week and your spouse or partner cares for your child during a night class 1 evening per week, you would mark YES and fill out questions 2 and 3.

1. What is the age of this child?

2. My child attends a childcare center, preschool, or nursery.

If YES: NO (skip to Q.3)

2A. How many hours per week? YES

2B. Approximately how much do you pay per month? \$

2C. This childcare center, preschool, or nursery is: (mark only one)

a. A reduced-cost center on campus at PSU (ASPSU or Helen Gordon)

b. A reduced-cost or sliding-scale center, such as YMCA or Head Start

c. _. A regular (full-cost) center.

d. _ Other center. Please specify

2D. All things considered, how satisfied are you with this childcare arrangement? (mark only one)

a.___ Very Satisfied

b. Somewhat Satisfied

c. Somewhat Concerned

d.___Very Concerned

3. My child is cared for in my home or someone else's home.

IF YES: NO (skip to Q.4)

3A. How many hours per week? YES

3B. Approximately how much do you pay per month? $\$$

$3 \mathrm{C}$. This care is provided by (mark all that apply)

a. An unpaid spouse or partner.

b. An unpaid relative, such as grandparent or aunt.

c. A paid relative.

d. A paid non-relative, such as a babysitter or daycare home.

3D. All things considered, how satisfied are you with this childcare arrangement? (mark only one)

a._Very satisfied

b. _Somewhat satisfied

c.__ Somewhat Concerned

d.__ Very Concerned

4. My child cares for him/herself.

IF YES: NO (skip to Question 10, page 3)

4A. How many hours per week? YES

4B. All things considered, how satisfied are you with this arrangement? (mark only one)
a._Very Satisfied
b.___Somewhat Satisfied
c. Somewhat Concerned
d.___ Very Concerned

Please continue on to Question 10, page 3. 
Fill out this page if your youngest child is in Kindergarten through High School.

Please provide information for EACH different type of care that you use for your youngest child. For example, if your child goes to school during the day and then your spouse or partner cares For them during your night class, you would mark YES and fill out questions 6 and 8 .

5. What is the age of this child?

6. My child attends kindergarten, grade school, middle school, or high school. YES

$6 \mathrm{~A}$. How many hours per week?

6B. Approximately how much do you pay per month? \$

6C. This school is (mark only one)

a. A public school

b. A private school

7. My child attends a before-school or after-school program.

IF YES:

NO (skip to Q.8)

7A. How many hours per week?

YES

7B. Approximately how much do you pay per month? $\$$

7C. This program is (mark only one)
a. Free
b. Reduced-Cost
c. Full Cost

7D. All things considered, how satisfied are you with this arrangement? (mark only one)
a. Very Satisfied
b. Somewhat Satisfied
c. _. Somewhat Concerned
d.___ Very Concerned

8. My child is cared for in my home or someone else's home.

IF YES: NO (skip to Q.9)

8A. How many hours per week? YES

8B. Approximately how much do you pay per month? \$

$8 \mathrm{C}$. This care is provided by (mark all that apply)

a. _ An unpaid spouse or partner.

b. An unpaid relative, such as grandparent or aunt

c. A paid relative

d. A paid non-relative, such as a babysitter or daycare home.

8D. All things considered, how satisfied are you with this arrangement?

a.___ Very Satisfied

b. Somewhat Satisfied

c. _. Somewhat Concerned

d.__ Very Concerned

9. My child cares for him/herself.

NO (skip to Q.10)

YES

IF YES:

9A. How many hours per week?

9B. All things considered, how satisfied are you with this arrangement? (mark only one)
a.__ Very Satisfied
b.__Somewhat Satisfied
c. _. Somewhat Concerned
d.___ Very Concerned 
10. Approximately how much do you pay per month for childcare for all of your children?

$\$$ per month.

11. Other than your income (including loans and financial aid), what resources do you have for childcare? (mark all that apply)

a._I have a spouse, partner, friend, or other family member who provides childcare free of charge.

b. _ I have reduced-cost daycare (like ASPSU or HGCDC) or sliding scale fees.

c. _ I receive a childcare scholarship (such as the Jim Sells Award).

d. _ I receive help from the government for childcare costs.

e. _ I have no additional resources, other than income, to pay for childcare.

f.___ Other resource(s). Please specify

12. How many credit hours are you taking this term?

13. Which best describes your current enrollment status? (mark only one)

a._L I am taking more credit hours than I would like. (skip to question 14)

b. _ I am taking just as many credit hours as I would like. (skip to question 14)

c. _ I am taking fewer credit hours than I would like.

13A. If you are taking fewer credit hours than you would like, why? (mark all that apply)

a. __ l am a full time employee.

b. _L Loss of Student Childcare Block Grant (Student Childcare Program)

c. _L Loss of job by self, spouse, or partner

d._. Not willing to take out extra student loans

e._. Financial Aid package was not enough

f._Difficulty paying for childcare costs

g. Unable to find satisfactory quality childcare (regardless of cost)

h.___Personal problems other than childcare or employment

i. _ I chose to spend more time with my child(ren)

j._ I have other care taking responsibilities

k. _ Conflict with work schedule

I.___other. Please specify

14. During the last term (Winter 2003), how often did you miss class because of problems with childcare? (mark only one)

a._No classes missed

b.__One or two classes missed

c. _. Three or four classes missed

d. _ Five or more classes missed

15. Considering your present situation, how certain do you feel about reaching your educational goals? (mark only one)

a. _. Very certain; I know I will be able to meet my educational goals.

b. _ Somewhat certain; I will probably be able to meet my educational goals

c. Somewhat uncertain; I am unsure that I will be able to meet my goals.

d. _ Very uncertain; I don't think I will be able to meet my educational goals. 
Finally, we'd like to ask you some questions about yourself.

16. What is your age?

17. What is your gender? Female Male

18. What is your marital (legal) status? (mark only one)

a.__ Single
b.___ Married
c.___ Divorced

d. Separated
e.___ Domestic Partner
f._Widowed

19. Which best describes your current living arrangements? (mark only one)
a.___Living alone (with children)
b.__Living with spouse or partner
d. ___ Living with parents or other relation
c.__Living with roommates (not including children)
e. Other. Please specify

20. Which best describes your race or ethnicity? (mark only one)
a. White/Caucasian (Non-Hispanic)
b. Black/African American
c. Hispanic/Chicano/Chicana
d. Asian/Pacific Islander
e. Native American
f.___ Multi-Racial. Please specify
g.__other. Please specify

21. How many children do you have and what are their ages?

Include all children that are your legal dependents.
a. One child. Age
b. Two children. Ages
and
c. Three children. Ages
and
d. _. Four or more children. Ages

22. What is the approximate gross income for your household? (mark only one) Household is defined as those with whom you share a dwelling and family responsibilities.
a._Under $\$ 5,000$
b. $\quad \$ 5,000-\$ 9,999$
c. $\$ 10,000-\$ 14,999$
d. $\$ 15,000-\$ 19,999$
e. $\$ 20,000-\$ 24,999$
f. ___ $\$ 25,000-\$ 29,999$

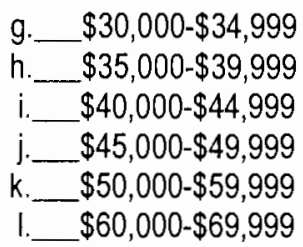

m. $\$ 70,000-\$ 79,999$

n. $\$ 80,000-\$ 89,999$

0. $\$ 90,000-\$ 99,999$

p. $\$ 100,000$ or above

23. What are the sources of income for your household? (mark all that apply)
a._My employment
b._._My spouse or partner's employment
c. _. Financial Aid Student Loans
d. Financial Aid Work Study
e. Child Support
f.___ Scholarships

g._Grants

h. Government Financial Assistance

i.___Parents, relatives, or friends

j.__Pension, Social Security, Disability

k. Food Stamps

I.__Other. Please specify 
24. How many hours per week do you work at a paid job? (including work study) hours/week.

25. What is your current university status? (mark only one)
a.___First-year
d._Senior
g. Doctoral
b. Sophomore
e._. Post baccalaureate
h. Non-admitted
c. Junior
f. Masters

26. What is your approximate overall grade point average (GPA)? (mark only one)
a. $\quad 0-1.99$
b. $\quad 2.0-2.5$
d. $\quad 3.1-3.5$
c. $2.51-3.0$
e. $\quad 3.51-3.75$
f. $\quad 3.76-4.00$

27. How much student loan debt do you currently have? (mark only one)
a. $\$ 0$
b. $\$ 1-\$ 4,999$
c. $\$ 5,000-\$ 9,999$
d. $\$ 10,000-\$ 14,999$
e. $\$ 15,000-\$ 19,999$
f. $\$ 20,000-\$ 24,999$

g. $\$ 25,000-\$ 34,999$

h. $\$ 35,000-\$ 44,999$

i. $\$ 45,000--\$ 54,999$

j. $\$ 55,000$ or above

28. Is there anything else you would like to say about childcare and how it affects your experience as a student? Do you have any ideas for resources on campus that would help you in your role as a student parent?

Thank you very much for participating in The PSU Student Parent Survey. Please return this survey by May 7 in the postage-paid envelope 


\section{Appendix C: Reminder Postcard}

Hello!

About a week ago you received the PSU Student Parent Survey in the mail. This research is part of my graduate work as a student in the Sociology Department at PSU. I sent you this survey so that we can obtain valuable information about student parents at PSU. The results of this important study will be presented to PSU school administrators and others who are responsible for resource allocation at PSU.

If you have already completed and returned your survey, thank you very much for your quick response. If you have not yet completed and returned your survey in the stamped, self-addressed envelope, please take time to do so. Your participation is critical for the success of this study.

If you have misplaced the survey or have other questions, please contact me at the address below.

Thank you for your participation,

E. Dawn Creach

Department of Sociology

Portland State University

PO Box 751

Portland, OR 97207-0751
Phone: 503-725-9025

E-mail: creach@pdx.edu 